IZA DP No. 7509

Can Parents' Right to Work Part-Time Hurt

Childbearing-Aged Women?

A Natural Experiment with Administrative Data

Daniel Fernández Kranz

Núria Rodríguez-Planas

July 2013 


\title{
Can Parents' Right to Work Part-Time Hurt Childbearing-Aged Women? A Natural Experiment with Administrative Data
}

\author{
Daniel Fernández Kranz \\ IE Business School
}

Núria Rodríguez-Planas

$I Z A, I A E-C S I C$ and UPF

Discussion Paper No. 7509

July 2013

IZA

P.O. Box 7240

53072 Bonn

Germany

Phone: +49-228-3894-0

Fax: +49-228-3894-180

E-mail: iza@iza.org

Any opinions expressed here are those of the author(s) and not those of IZA. Research published in this series may include views on policy, but the institute itself takes no institutional policy positions. The IZA research network is committed to the IZA Guiding Principles of Research Integrity.

The Institute for the Study of Labor (IZA) in Bonn is a local and virtual international research center and a place of communication between science, politics and business. IZA is an independent nonprofit organization supported by Deutsche Post Foundation. The center is associated with the University of Bonn and offers a stimulating research environment through its international network, workshops and conferences, data service, project support, research visits and doctoral program. IZA engages in (i) original and internationally competitive research in all fields of labor economics, (ii) development of policy concepts, and (iii) dissemination of research results and concepts to the interested public.

IZA Discussion Papers often represent preliminary work and are circulated to encourage discussion. Citation of such a paper should account for its provisional character. A revised version may be available directly from the author. 


\title{
ABSTRACT
}

\section{Can Parents' Right to Work Part-Time Hurt Childbearing-Aged Women? A Natural Experiment with Administrative Data}

\begin{abstract}
Using a differences-in-differences approach and controlling for individual unobserved heterogeneity, we evaluate the impact of a 1999 law that granted all workers with children younger than 7 years old protection against a layoff if the worker had previously asked for a work-week reduction due to family responsibilities. As only mothers took advantage of these arrangements, we find that after the law, employers were: (i) more likely to let childbearingaged working women "go" relative to their male counterparts; (ii) less likely to promote childbearing-aged women into good jobs; and (iii) less likely to hire childbearing-aged women. In addition, employers were able to pass at least part of the cost to childbearingaged women through lower wages, and the amount passed to workers increased with the precariousness of the job. Heterogeneity analysis reveals that the effect on employment transitions is mainly driven by low-skilled workers and those in blue-collar jobs, while the effect on wages holds across all groups. Evidence that the substitution away from (good) jobs widens over time suggests employer learning. These results are robust to the use of different specifications and placebo tests.
\end{abstract}

JEL Classification: $\quad$ C23, C25, C33, J16, J22, J62

Keywords: female employment transitions and wages, fixed-term and permanent contract

Corresponding author:

Núria Rodríguez-Planas

Visiting Research Fellow

IZA

P.O. Box 7240

53072 Bonn

Germany

E-mail: rodriguez-planas@iza.org

\footnotetext{
* We are very grateful to Samuel Bentolila, Richard Blundell, Laura Hospido, Marcel Jansen, Laura Hospido, and participants of seminars at the Banco de España, and the 2012 and 2013 ESPE conference.
} 


\section{Introduction}

As American families are craving for flexible work arrangements to care for young children and/or older relatives while also managing job requirements, many researchers and policy makers believe that having access to the right to request part-time work and being protected from retaliation for asking could be the solution (New York Times, 14 June 2013). Sweden, the United Kingdom, New Zealand, Australia, Germany, Spain, and The Netherlands have, by law, told employers that they cannot unreasonably refuse an employee's request for a part-time or nonstandard schedule. Employers should "seriously consider" such requests, and not discriminate against those who ask. Furthermore, employees can also seek to return to full-time work as their needs change. In 2007, representative Carolyn Maloney, with co-sponsorship by Senators Barack Obama, Edward M. Kennedy and Hillary Rodham Clinton, introduced similar legislation, which was stalled in Congress (New York Times, 19 January 2013). The current paper analyzes the effects of introducing such type of legislation on childbearing-aged women's employment transitions and wages. To the best of our knowledge, this is the first paper to estimate the effects of such type of reform, using a Differences in Differences (DiD thereafter) approach that controls for individual fixedeffects. To achieve this, our study uses high-quality longitudinal data from SocialSecurity records with accurate quarterly employment and wage information that allows us to avoid many problems encountered using survey data.

Our analysis focuses on whether the law had unintended effects on women in their prime-childbearing age years, regardless of their family status. Given that women are the main users of this new law, men constitute a reasonable comparison group, and the "natural" experiment examines how the law affects the gap between female and male outcomes. We find that, after the law, employers were 5 percent less likely to hire 
childbearing-aged women relative to men. Among those working, employers were between 40 and 45 percent more likely to let childbearing-aged women go from jobs, and 37 percent less likely to promote childbearing-aged women to good jobs. Our estimates provide strong evidence that by targeting employment protection for a specific group of workers, the legislator has induced substitution from childbearing-aged women to childbearing-aged men. In addition, we find that employers are also able to pass at least part of the cost to childbearing-aged women through lower wages, and the amount passed to workers increases with the precariousness of the job. These findings are robust to the use of alternative specifications and alternative control groups. Moreover, placebo estimates using a pre-reform period support the assumption that our results on the effects of the law are not spurious. Heterogeneity analysis reveals that the effect on employment transitions is mainly driven by low-skilled workers and those in blue-collar jobs, while the effect on wages holds across all groups. Finally, we find evidence that employers learn over time and consequently the substitution away from (good) jobs widens.

We also find that the reform was only partially successful in terms of enabling mothers with small children to move into part-time work, since only those with a permanent work arrangement show a larger propensity to switch to part-time after the law. Our estimates show that the relative odds of moving from full- to part-time work increased by 133 percent for mothers with permanent work arrangements with children younger than 7-years old relative to those with children aged 7- to 12-years old. This is driven by those who move to part-time work without a job change. No effect of the law is found among fathers of children under 7 years old relative to fathers of children aged 7- to 12-years old, even though they could have also requested the work-week reduction by law. 
Using administrative data offers at least three advantages over survey data. First, we observe all employment transitions that take place between jobs, part- and fulltime status and contract type, and non-employment from 1996 to 2010. Moreover, we have access to contractual monthly wages and hours to calculate the hourly wages, eliminating the problem of measurement error owing to recall bias or non-response. Second, as we have longitudinal as opposed to cross-sectional data, we can control for individual fixed-effect. Third, we have a large number of both childbearing-aged men and women for whom we observe their employment transitions both before and after the law change, enabling us to identify with precision each of the individual fixed-effects estimators.

These findings contrast with those from the literature on mandated maternity benefits, which find detrimental effects of such benefits on women's wages relative to men (in the US and Europe) but positive (in Europe and Taiwan) or non negative (in the U.S) effects on women's employment (see Gruber 1994, Ruhm, 1998, Zveglich and Meulen Rodgers, 2003). ${ }^{1} \quad$ Most studies analyzing parental leave schemes focus on schemes that give mothers the right to not work while their child is a baby or a toddler (with or without pay) and return to a job that is comparable to the one held before childbirth. However, to the best of our knowledge, there is no causal evidence on the effects of the right to request a work-week reduction to reconcile family life and work. In this case, parents continue to work in the same job, but with a reduced work-schedule until their youngest child reaches a certain age (typically 6 or 8 years of age). Thus, the

\footnotetext{
${ }^{1}$ Most studies analyzing the effects of family leave on maternal employment find no or very small negative effects on maternal employment or wages, at least in the long-run (Klerman and Leibowitz 1997, 1999; Albrecht et al. 1998; Waldfogel 1998, 1999; Baum 2003; Lalive and Zweimüller 2009). However, some exceptions emerge; for instance, Schönberg and Ludsteck (forthcoming), find that a reform that extended the maternity benefit period beyond the job protection period discouraged mothers to return to work and lowered their labor market income.
} 
unintended employment and wage effects of such protective measures for women in general may be large.

We estimate the impact of the Spanish Law 39/99, implemented on November 5, 1999, in which the government granted all wage and salary workers with children under 7 years old the right to work part-time. Most importantly, the law also established that once the worker has asked for a work-week reduction due to family responsibilities, she cannot be laid off. Spain offers an interesting case to investigate the effects of protective measures for working mothers because it obliged employers to grant any requests and protected workers who had requested to work part-time.

This paper also contributes to the literature on the effects of part-time work on women's employment careers (see Gornick and Hegewisch 2011; and Fernández-Kranz and Rodríguez-Planas 2011). Nonetheless, most of that literature is not causal, given the extreme difficulty in finding good instrumental variables to address the selection problem into part-time work (Manning and Petrongolo 2008). This paper is close to Fouarge and Baaijens (2009) and Munz (2004) in that these authors analyze the effects of laws giving the right to work part time. However, in contrast to our paper, these authors analyze the effects of giving the right to work part time to all employees, and find small or negligible effects on hours worked (Fouarge and Baaijens, 2007), and on the likelihood to switch from full- to part-time work without changing jobs (Munz 2007). Another relevant paper is that of Fitzenberger et al. 2012, which estimates the effect of two simultaneous laws on maternal employment that took place in Germany in 2001: a policy reform providing financial incentives for an earlier return-to-job after childbirth, and a legal claim for part-time work and regulated fixed-term contracts for all workers. They find that the joint effect of the law increased maternal employment. 
The remainder of this paper is organized as follows. The next section describes the institutional background and the 39/1999 law. Section III presents the empirical strategy. Section IV presents the data and descriptive statistics. Section V presents the results and Section VI concludes.

\section{Institutional Background}

\section{The Spanish Segmented Labor Market}

In 1984, Spain (like many Continental European countries during the mid-1980s) reformed its employment protection rules to add flexibility in the labor market by encouraging the use of fixed-term contracts. Consequently, fixed-term contracts quickly soared, with close to one-third of wage and salary workers in Spain working under a fixed-term contract by the early-1990s (Bentolila, Dolado and Jimeno 2008). In contrast with permanent contracts, fixed-term contracts have much lower dismissal costs and its termination cannot be appealed to labor courts. Furthermore, these contracts have a much lower severance payment (12 days' wages per year of service as opposed to 45 , and a maximum duration of 36 months within the same firm instead of 42). ${ }^{2}$ Moreover, the regulation that established that fixed-term contracts could only be used up to a maximum of three consecutive years was not enforced until 2010. Consequently, the majority of workers in Spain initiate their employment history with a fixed-term contract and as many as 40 percent of them still hold such type of contract ten years later (Estrada et al. 2009). In Spain, the average duration of a fixed-term contract is less than three months. While fixed-term duration contracts coexist with permanent contracts within the same firms in Spain, they impose penalties to workers in the form of forgone experience, delayed wage growth and higher levels of

\footnotetext{
${ }^{2}$ A recent labor market reform that reduced permanent contracts' severance payment to 33 days was passed in February 2012.
} 
unemployment risk (Amuedo-Dorantes and Serrano-Padial 2007). According to Amuedo-Dorantes and Serrano-Padial (2007), turnover rates among fixed-term contract workers are high (in the range of 34 to 66 percent), and contrast with those of permanent contract workers (only 10 percent of permanent contract workers experience turnover). Moreover, while the vast majority of job movers with a fixed-term contract transition to a new fixed-term contract job or become unemployed, those with a permanent contract transition to a new permanent contract job or retire. Furthermore, workers under fixed-term contracts have been found to exhibit lower rates of absenteeism (Jimeno and Toharia 1996; Ichino and Riphahn 2005; Olsson 2009) and greater rates of unpaid overtime work (Engellandt and Riphahn 2005). Finally, and importantly for our study, a large strain of literature has found that fixed-term contract workers are in general working under worse conditions related to work-family balance, such as less favorable working schedules (Amuedo-Dorantes 2002) and having less ability to exert control over their own work (Beard and Edwards 1995).

\section{The 39/1999 Law}

On November 5, 1999, the Spanish Government passed the 39/1999 Law to Promote the Conciliation of Work and Family Life, which entered into effect the day after its publication. It granted the right to request a work-week reduction only to parents of small children, regardless of sex or contract type. More specifically, it entitled wage and salary workers with children under 7 years old to ask for a reduction of between one-third and one-half of the usual full-time schedule, with an equivalent reduction in their monthly salary. ${ }^{3}$ In addition, workers are entitled to return to their full-time schedule upon request, and have the right to choose the time slot during the day they want to work. Most importantly, the law declared a dismissal or layoff invalid if the

\footnotetext{
${ }^{3}$ The maximum age of the child was extended from 6 to 8 in 2007 .
} 
worker had previously asked for a work-week reduction due to family responsibilities, namely the firm must readmit workers in their previous job and cannot use the alternative of dismissing the worker by compensating with the statutory severance payment.

It is important to note that although this law declares a layoff invalid if the worker has previously asked for a work-week reduction due to family responsibilities, de facto it only protects workers with permanent contracts, given that employers who do not want to offer reduced work hours to workers with fixed-term contracts only have to wait for their contract to expire to terminate the employment relationship.

Although the objective of the law is to promote the conciliation of work and family life, it may end up causing the opposite effect for some women if employers hire fewer childbearing-aged women (regardless of whether or not they have children) all together or limit them to jobs in which such law is less binding and with worse conditions for work-family balance, such as jobs under fixed-term contracts, thereby increasing type-of-contract gender segregation. The reason for this is that childbearingaged women are likely to potentially use the reduced work schedule in the future (and gain increased job protection until their youngest child reaches the age of 7). If this concern exists, we should see fixed-term contract work increasing and permanent contract work decreasing for at-risk women, relative to their male counterparts.

Due to the traditional values of Spanish society, we do not expect working fathers to access part-time work. In Spain, most people believe that it is optimal for young children to spend most of their time during the first few years of their life under their mother's care (Pfau-Effinger 2006). Despite a recent change in attitudes, child care remains a women's main responsibility, and although Spanish men have recently increased the amount of time spent taking care of their children (Larrañaga et al. 2004), 
there is still a strong asymmetry in the share of childbearing responsibilities across gender with women spending an average of 2.7 more hours per day with their children than men (Marí-Klose et al. 2010). Moreover, given that men tend to have higher earnings than women in Spain, the decision to reduce the work schedule of the lower earning member of the household is also a rational one. In section III, we present evidence consistent with mothers of children under 7 years old being more likely to access part-time employment under permanent contracts after the reform. No such effect is found among fathers of children under 7 years old.

\section{The CSWH Data}

We use data from the 2010 wave of the Continuous Sample of Working Histories (hereafter CSWH), which is a 4 percent non-stratified random sample of the population registered with the Social Security Administration in 2010. The CSWH provides information on: (1) socio-demographic characteristics of the worker (such as sex, education, nationality, province of residence); (2) the worker's job information (such as type of contract, part-time status, occupation, the dates the employment spell started and ended, and monthly earnings); and (3) employer's information (such as industry, public versus private sector, the number of workers in the firm, and the location). ${ }^{4}$ Despite not being reported in the CSWH, other variables such as experience and tenure can easily be calculated. ${ }^{5}$ In addition, information on the individual's education level, and the number and date of birth of children living in the household at the time of the interview (including but not distinguishing own natural, adopted, step and foster children)

\footnotetext{
${ }^{4}$ Working part-time is defined as working less than 30 hours per week.

${ }^{5}$ As we lack information on reason for not working, we record spells of non-work as the time the person is not employed.
} 
is available in the 2010 Spanish Municipal Registry of Inhabitants, which is matched at the person level with the Social Security records.

We use quarterly data from the first quarter of the 1996 until the last quarter of 2010 (keeping only the last month of each quarter), focusing our analysis on 4 years prior to and 11 years after the law. The reason for limiting our analysis to the post-1996 period is that the CSWH does not provide reliable information on type of contract prior to 1996 . However, we use information back to 1985 to calculate variables such as workers' experience and tenure. In the CSWH, we observe the work history of individuals: (i) working in 2010, or (ii) not working in 2010, yet receiving Social Security benefits, which include unemployment benefits, disability, survivor pension, and maternity leave. Thus, individuals without a valid relationship with the Social Security in 2010 are not present in the database. ${ }^{6}$

We restrict our analysis to private sector wage and salary workers, and prime childbearing-aged individuals - defined as men and women between 23 and 44 years old (both included), given that they are most at-risk of being potentially eligible. ${ }^{7}$ Immigrants are excluded from the analysis. We divide our population into three samples. One sample includes all workers observed at two successive interviews and who were not working during the previous quarter, which is used to study the effects of the reform on hiring. The other two samples are used to study the impact of the reform on those who were already working in the previous quarter under a permanent and fixed-term contract, respectively. Unfortunately, the CSWH lacks information on the reason why a worker is no longer working at survey date, precluding us from analyzing

\footnotetext{
${ }^{6}$ By comparing different waves of the CSWH, one can get a sense of the magnitude of this type of attrition among women between 23 and 44 years old, which is those under analysis in this paper. From our calculations, we found that among those women who were in the Social Security records the previous year, as few as 3.4 per cent of mothers and 3.8 per cent of childless women were attrited the following year.

${ }^{7}$ The average age at which most Spanish women had their first child was 28 years old in 1970 and 30 years old in 1995. Moreover, only 4 percent of mothers had their first child at age 35 or older.
} 
the effects of the reform on being laid-off. Thus, our results on the likelihood of remaining employed include both labor supply and demand responses to the law. ${ }^{8}$

The final three samples include three unbalanced panels of $37,321,52,094$ and 42,591 women and 31,912, 43,700 and 34,435 men. Although our econometric analysis focuses on the period between 1996 and 2010, individuals are in the CSWH between 1 and 25 years. In our sample, each woman (man) is observed for 48.20 (50.45) quarters on average, resulting in 1,590,952 woman-quarter observations and 1,388,212 manquarter observations.

\section{Empirical Strategy}

\section{Compositional Bias in the Standard DiD Estimator}

In order to explore whether employers substituted away from female labor, we compare employment transitions of prime childbearing-aged women with those of men within the same age range before and after the reform. We can estimate the policy effect as a difference in difference (DiD):

$$
\begin{aligned}
& D i D=E\left[Y_{i t} \mid S(i)=\text { Women,Post_1999=1, } X_{i t}\right]-E\left[Y_{i t} \mid S(i)=\text { Women,Post_1999=0, } X_{i t}\right] \\
& -\left\{E\left[Y_{i t} \mid S(i)=\text { Men,Post_1999=1, } X_{i t}\right]-E\left[Y_{i t} \mid S(i)=\text { Women,Post_1999=0, } X_{i t}\right]\right\}
\end{aligned}
$$

To put this in a regression, the model can be written as:

$$
Y_{i t}=\alpha_{0}+\alpha_{1} \text { Post_1999 }{ }_{i t}+\alpha_{2}\left(\text { Women }_{i} * \text { Post_1999 } i t\right)+\beta X_{i t}^{\prime}+\gamma_{i}+u_{i t}
$$

where $t$ indexes the quarter, and $i$ indexes the individual. The variable $W_{o m e n}$ is a dummy variable indicating whether the individual is a woman, and the variable Post_1999 is a dummy equal to 1 after the year 1999 (and 0 otherwise). $X_{i t}$ is a vector

\footnotetext{
${ }^{8}$ Using the longitudinal CSWH offers many advantages over the Spanish Labor Force Survey, which is cross-sectional. First, while annual employment transitions can be constructed using a question in the Spanish LFS that asks about last year's employment, they are based on individuals' response, which may be affected by recall bias. Second, no information is provided on the type of contract or part-time status of the job worked during the last year reducing the scope of analysis. Finally, wages are not reported in the Spanish LFS.
} 
of control variables. The error term includes both a random component $\mu_{i t}$ with mean zero and constant variance, and a worker-specific fixed effect, $\gamma_{i}$.

Taking the expectation of the outcome of interest $Y_{i t}$ conditional on being a woman before and after the law and conditional on being a man before and after the law, we get:

$$
\begin{aligned}
& E\left[Y_{i t} \mid S(i)=\text { Women,Post_1999 }=1, X_{i t}\right]=\alpha_{0}+\alpha_{1}+\alpha_{2}+\beta+E\left[\gamma_{i} \mid S(i)=\text { Women,Post_1999=1, } X_{i t}\right] \\
& E\left[Y_{i t} \mid S(i)=\text { Women,Post_1999 }=0, X_{i t}\right]=\alpha_{0}+\beta+E\left[\gamma_{i} \mid S(i)=\text { Women,Post_1999=0, } X_{i t}\right] \\
& E\left[Y_{i t} \mid S(i)=\text { Men,Post_1999 }=1, X_{i t}\right]=\alpha_{0}+\alpha_{1}+\beta+E\left[\gamma_{i} \mid S(i)=\text { Men, Post_1999=1, } X_{i t}\right] \\
& E\left[Y_{i t} \mid S(i)=\text { Men,Post_1999 }=0, X_{i t}\right]=\alpha_{0}+\beta+E\left[\gamma_{i} \mid S(i)=\text { Men,Post_1999=0, } X_{i t}\right]
\end{aligned}
$$

The standard DiD model estimated with OLS assumes that the expectation of unobserved individual heterogeneity of women (and men) before and after the reform remain unchanged and thus cancel each other out when estimating the $\mathrm{DiD}$ estimator. Namely, it assumes that:

$$
\begin{aligned}
& E\left[\gamma_{i} \mid S(i)=\text { Women,Post_1999=1, } X_{i t}\right]=E\left[\gamma_{i} \mid S(i)=\text { Women,Post_1999=0, } X_{i t}\right] \\
& E\left[\gamma_{i} \mid S(i)=\text { Men,Post_1999=1, } X_{i t}\right]=E\left[\gamma_{i} \mid S(i)=\text { Men,Post_1999=0, } X_{i t}\right]
\end{aligned}
$$

However, it is likely that this reform modified the hiring practices of employers by making them more selective when hiring women, choosing only the most productive female workers. If this is the case, the coefficient $\alpha_{2}$ would underestimate the negative effects of the reform on the probability of not promoting women or dismissing them. An alternative and possibly complementary effect of the reform is that the composition of working women changes, in that by allowing mothers to work part-time while their youngest child is 0- to 7-years old, the reform may have led to a reduction in the number of women who would have chosen not to work in the absence of the policy. Depending on whether these women are of higher or lower quality than those who did 
not exit employment prior to the reform, $\alpha_{2}$ will overestimate or underestimate the causal effect of the reform on continuing employed.

An additional concern of this standard DiD is that it does not control for timeinvariant individual unobserved heterogeneity. This is important given that it is likely that some workers "abuse" this law by asking for a work-week reduction to prevent a layoff. If it is mainly lower productivity workers who seek and gain this extra protection, then $\alpha_{2}$ will again bias the impact of the reform.

\section{Individual Fixed-Effects Estimator of the Reform}

To address these concerns, our preferred estimate is the DiD within-individual estimator, which we obtain by running the following fixed-effects (FE) regression (1): ${ }^{9}$ $Y_{i t}=\alpha_{0}+\alpha_{1}$ Post $_{-} 1999_{i t}+\alpha_{2}\left(\right.$ Women $_{i} *$ Post $\left._{-} 1999_{i t}\right)+\alpha_{3}$ Trend $_{t}+\alpha_{4}\left(\right.$ Trend $_{t} *$ Women $\left._{i}\right)$ $+\beta_{1} X_{i t}^{\prime}+\beta_{2}\left(X_{i t}^{\prime} *\right.$ Women $\left._{i}\right)+\gamma_{i}+u_{i t}$

where the vector $\mathrm{X}_{\mathrm{it}}$ includes individual-level variables expected to be correlated with employment: age and age squared, years of education, a variable indicating the number of children in the household, and all these variables interacted with the female dummy. We also include Comunidad Autónoma (Region) dummies and the Comunidad Autónoma's unemployment rate as additional controls. In order to control for possible pre-period trends that could bias the results (Meyer, 1995), we also include a linear (quarterly) time trend, Trend, which differs for the treatment and control group, enabling us to control for systematic differences in the behavior between the two groups over time. At the end of the results section, we test the robustness of our results to alternative trend specifications, including one specification with year fixed effects. Standard errors are robust and allow for intra-cluster (individual) correlation.

\footnotetext{
${ }^{9}$ While the standard fixed-effects model is equivalent to the first difference with a balanced panel and no covariates, this is not true when one has an unbalanced panel and adds controls for observable characteristics.
} 
We estimate this regression separately for 6 outcome variables, measuring transition probabilities from working under a permanent contract, a fixed-term contract, or not working during quarter $(t-1)$ to working under a permanent contract, or not working during quarter $(t)$. This enables us to disentangle the effects of the law on: $(i)$ the likelihood of remaining employed under the same type of contract; (ii) the likelihood of being promoted from a fixed-term to a permanent contract, and (iii) the likelihood of being hired into either type of contract. At the end of the results section, we also present estimates of the effects of the reform on wages.

The coefficient $\alpha_{2}$ on the interaction between Post_1999 ${ }_{t}$ and Women $_{i}$ captures the change in transition probabilities of women after the reform relative to before the reform, as well as relative to the within transition changes of men net of any underlying trends. Due to the inclusion of individual FE, identification of $\alpha_{2}$ comes solely from those women and men observed before and after the change of the law. In this case, it is important to note that the assumption is that the individual unobserved heterogeneity remains time invariant before and after the reform. This assumption is not as stringent as that taken with the standard DiD, namely that the average unobserved heterogeneity of women (and men) before and after the reform remains unchanged. The latter is a standard assumption within the DiD literature, as most of the research either uses crosssectional data or does not estimate FE estimator, even when using longitudinal data. ${ }^{10}$ To reduce the compositional bias concern, many $\mathrm{DiD}$ studies focus on the effects of the reform a couple of years before and after the reform. However, this does not solve the problem of time-invariant unobserved heterogeneity. An additional advantage of focusing the analysis on the years close to the reform is that it minimizes concerns

\footnotetext{
${ }^{10}$ As discussed below, one needs a large longitudinal sample to identify the within-estimator DiD coefficient, as identification only comes from those observed transitioning before and after the reform. Our data set is both long and large as it comes from administrative data.
} 
regarding potential policy interactions. Given that employer learning may take place, it is deemed important to analyze the longer-run effects of such a reform. Thus, we present estimates of the immediate effects of the reform versus the longer-term effects in the results section, using an alternative specification that replaces the post 1999 dummy with two time dummies (covering the years 2000 to 2004 and post 2004) and their interaction with the treatment dummy. In addition, at the end of Section IV, we conduct several robustness checks to address potential identification threats.

\section{Identification of the within-individual DiD estimator}

It is important to note that we have a large number of both childbearing-aged men and women for whom we observe their employment transitions both before and after the law change in order to identify with precision each of the individual FE estimators. When we condition on having a permanent contract during (t-1), we observe 4,486 childbearing-aged men and 4,028 women both before and after the reform. Similarly, when we condition on having a fixed-term contract during (t-1), we observe 3,170 men and 4,953 women both before and after the reform. Finally, when we condition on not working at $(t-1)$, we observe 1,925 men and 3,538 women both before and after the reform.

\section{Choice of the Comparison Group}

A final concern relates to the choice of our comparison group. Our identification strategy relies on the assumption that, after the law, employers' expected costs of hiring childbearing-aged women have increased relative to those of hiring childbearing-aged men. However, for this to be the case, we need to observe that: (i) the reform was effective for the eligible population, namely that mothers whose youngest child is under 7 years old made the transition from full- to part-time work after the reform; but (ii) not all workers with access to the family-friendly policy, namely fathers with children under 
7-years old, use the right to request the flexible work arrangement (otherwise the relative expected cost of hiring childbearing-aged women relative to childbearing-aged men would not have changed after the law). Table 1 analyzes the effect of the reform on the employment transitions from full- to part-time work for mothers (panel A) and fathers (panel B) with children under 7 years-old, presenting individual FE estimator of the reform as explained above. However, we use different treatment and control groups, whereby the treatment groups include parents whose youngest child is under 7 years old, while the control groups include parents whose youngest child is 7 to 12 years old (both included) and who were not affected by the law when their child was younger. The latter restriction limits our analysis to the 1996-2004 period, as we subsequently run out of individuals in the comparison group. Panel $\mathrm{A}$ in Table 1 shows that the reform led to a relative increase in the likelihood of working part-time among mothers of children under 7 years old who worked full-time under a permanent contract during $(t-1)$. The coefficient reveals that the law led to a 0.4 percentage points (or 133 percent) increase relative to the working mothers with slightly older children. This coefficient is statistically significant at the $5 \%$ level. When we estimate the effect of the reform on the likelihood of moving into part-time work conditional on staying with the same employer, the effect is even larger for mothers of children under 7 years old with a permanent contract during quarter $(t-1)$. For such mothers, the reform increased the likelihood of part-time work by 0.6 percentage points or 200 percent. We also observe that the law reduced the likelihood of eligible mothers with a permanent contract during (t-1) moving to part-time work when switching employers, with this relative probability decreasing by 14.5 percentage points (or 179 percent). Thus, the law was very effective at fostering part-time work among mothers of small children who had been working under a permanent contract. In contrast, we find no significant effects of the law on 
mothers' transition into part-time work for those who had been working under a fixedterm contract during $(t-1)$. Overall, these results confirm our intuition that only workers protected by a permanent contract used the leeway granted by the new law and that workers with no such protection (those under a fixed-term contract or who changed employers) did not exercise their rights, possibly due to the fear of being rejected by their employers.

Panel B shows similar estimates for fathers with small children, finding that the reform had no effect on the transition from full- to part-time employment, as anticipated. Given that we find no effects of the law on the likelihood of transitioning into a part-time job among fathers of small children, we assume that the reform also had no effect on non-fathers. Finally, Panel C presents a placebo test using only pre-reform data and mothers. None of the coefficients are statistically significant, providing evidence that earlier findings for mothers do not capture a spurious relationship.

\section{Main Results}

\section{Descriptive Statistics}

Table 2 displays pre-reform descriptive statistics for the socio-demographic differences across the treated and comparison groups for the three samples under analysis: those working under a permanent contract during quarter ( $t-1)$, those working under a fixedterm contract during quarter (t-1), and those not working during quarter ( $t-1)$. Treatment and control groups are quite similar within and between each group of implementers. Overall, we observe that women are older, more educated and more likely to have children than men. As explained earlier, our specifications control for these observable differences. 
We are particularly interested in measuring the effect of the reform on the likelihood of women: (i) retaining permanent contracts; (ii) being promoted from fixedterm to permanent contracts; (iii) leaving (permanent or fixed-term) employment; and (iv) entering employment. Table 2 shows that, before the reform, the likelihood of retaining a permanent contract was on average 95 percent among prime childbearingaged women and 96 percent among men, indicating quite some persistence into permanent employment. In contrast, the likelihood of being promoted from a fixedterm to a permanent contract (regardless of whether there is an employer change) is quite low for both the treatment and control group, given that only 5 percent of women and 6 percent of men move from a fixed-term to a permanent contract before the reform (this estimate is consistent with that of Güell and Petrongolo 2007, using an alternative dataset, the Labor Force Survey). As one would expect given the duality of the Spanish labor market, the odds of leaving a permanent contract are quite low (less than 2 percent) for both groups, especially in comparison with the odds of leaving fixed-term contract employment, which are 13 percent for men and 15 percent for women. Finally, Table 2 shows that the odds of entering employment before the reform were 26 percent for men and 24 percent for women, with most of entries (98 percent) being into a fixedterm contract.

One concern is the potential endogeneity of our policy. For example, we may worry that the law was the government's response to a lack of employment growth among childbearing-aged working women. To address this concern, Figure 1 draws three transition probabilities for the period under analysis, namely from 1996 to 2010 , for both the at-risk (women between 23 and 44 years old) and comparison groups (men between 23 and 44 years old): (i) the likelihood of entering employment - shown in Panel A; (ii) the likelihood of being promoted from a fixed-term to a permanent 
contract — shown in Panel B; and (iii) the likelihood of exiting employment (from a fixed-term contract job) — shown in Panel C. ${ }^{11}$ The outcome series plotted are (forward) moving averages using quarterly data of the detrended transition probabilities. ${ }^{12}$ The vertical line separates the pre- and post-reform period. Below, we summarize the main findings from Figure 1.

Panel A of Figure 1 shows that the odds of entering employment prior to the reform were slightly higher for women than for men in the mid-1990s, before converging by the end of the 1990s. These odds begin to differ within one year following the reform, as the likelihood of entering employment decreases more for women than men over time, suggesting that employers relatively prefer hiring the latter than the former. Panel $\mathrm{B}$ of Figure 1 shows the odds of being promoted from a fixed-term to a permanent contract. In this Panel, the alternative work status is continuing employment under a fixed-term contract, and thus panel B conditions on being employed at time t. In panel C, we analyze the probability of exiting employment from fixed-term contract. In panel B we see that while women's likelihood of moving into a permanent contract is close to that of men before the reform, a gap across genders emerges thereafter, indicating that employers are less likely to promote women to permanent contracts than men. Panel C of Figure 1 shows that the likelihood of moving from fixed-term employment to nonemployment was higher among women than men before the reform. Nonetheless, this gap widens considerably after 1999, suggesting that employers are relatively less likely to renew fixed-term contracts to women.

\footnotetext{
${ }^{11}$ Given the persistence within permanent employment and the difficulties of laying off workers under a permanent contract, the transition from permanent employment to non-employment is quite infrequent.

${ }^{12}$ The detrended probabilities come from regressions that control for age, region and a linear time trend.
} 


\section{Did the Reform Lead to a Substitution Away from (good) Jobs for Childbearing-Aged}

Women?

Table 3 shows our preferred estimates: the DiD estimator controlling for individual fixed effects. All models control for a dummy equal to one if the individual is a woman and zero otherwise, education, education interacted with the woman dummy, number of children and number of children interacted with the woman dummy, age, age squared, region dummies, the regional unemployment rate, a linear time trend, a linear time trend interacted with the woman dummy, a post-1999 dummy, and the interaction of between this variable and the woman dummy. The regressions where the dependent variable is a transition from one contract type to another condition on working at $t$, and therefore estimate the probability of moving into one contract type as opposed to another type. Columns 1 to 3 from Panel A of Table 3 display the estimated impacts of the reform on the likelihood of moving into a permanent contract (row 1) and out of employment (row 2) for childbearing-aged women using our preferred specification, namely the within individual FE model. Column 1 presents estimates for workers with a permanent contract during $(t-1)$, thus displaying the effect of the reform on remaining employed under a permanent contract (row 1), as well as on exiting permanent employment into non-employment (row 2). Column 2 presents estimates for workers with a fixed-term contract during $(t-1)$, thus displaying the effect of the reform on being promoted to a permanent contract--regardless of whether this implies employer change--(row 1), as well as on exiting fixed-term employment into non-employment (row 2). Column 3 presents estimates for individuals not working during $(t-1)$, thus displaying the effect of the reform on obtaining a permanent contract conditioned on employment at $t$ (row 1), as well as on remaining non-employed at $t$ (row 2). Columns 1 to 3 from Panel B display the OLS estimates. 
What were the effects of the reform on childbearing-aged working women? We observe that employers were more likely to let working women "go" after the reform, relative to their male counterparts. Indeed, this is observed in columns 1 and 2 in row 2 from Panel A of Table 3. The 1999 law led to a relative increase of 0.5 percentage points in the likelihood of moving from a permanent employment to non-employment. Since only 1.1 percent of childbearing-aged women transitioned from permanent employment to non-work prior to the law, this implies that the policy increased the relative odds of leaving employment in the primary segment of the labor market by 45 percent. The drain is similar in the secondary segment of the labor market, whereby we observe that, after the reform, childbearing-aged women were 40 percent (or 4.7 percentage points) relatively more likely to transition from a fixed-term contract into non work. Comparing the within FE estimators to the OLS estimates (in Panel B of Table 3) reveals an interesting insight: the reform led to a negative selection into the primary sector of the labor market but a positive one into the secondary segment of the labor market. Although the sign of both coefficients is the same, the OLS coefficient of the reform is larger than the FE coefficient among workers holding a permanent contract during $(t-1)$, indicating negative unobserved heterogeneity in the primary segment of the labor market. This suggests that, after the law, less productive (or less motivated) women decide to remain in the primary segment of the labor market, as the law reduces their relative costs of working in such a segment. In contrast, the opposite is observed among women with a fixed-term contract. The OLS estimator is smaller in size than the FE estimator suggesting positive unobserved heterogeneity in the secondary segment of the labor market. Notice that as the law is more binding under a permanent contract (as with a fixed-term contract, the employer only has to wait for the contract to expire to terminate an employment relationship), the costs of working in the 
secondary labor market have increased relative to the primary labor market, which would explain the positive selection into fixed-term contract work. An alternative and complementary explanation is that due to it being considerably more attractive for women to enter the primary labor market, many high productivity women who would not have stayed in a fixed-term contract prior to the reform now do so as a steppingstone into a permanent job. Despite it being difficult to move from a fixed-term to a permanent contract, it is important to highlight that the majority of workers in Spain, around 90 per cent, initiate their employment history with a fixed-term contract (Estrada et al., 2009). Finally, if employers dislike the new workers' rights granted by the law, they may get rid of female workers in fixed-term contracts and only keep those with higher relative productivity, which would also explain the positive selection in the secondary segment of the labor market observed in the data.

After the reform, do we observe that employers are less likely to promote women to permanent contract jobs relative to their male counterparts? Indeed, we observe in the first row of column 2 that the likelihood of moving from a fixed-term contract into a permanent contract job after the reform decreased by 1.7 percentage points among childbearing-aged women relative to their male counterparts. Remember that in this row we control for being employed at time $t$; therefore, the estimated coefficient indicates exclusively the probability of a transition from fixed-term to a permanent contract. Since the odds of transitioning from a fixed-term to a permanent contract among women prior to the reform was 4.6 percent, this represents a 37 percent decrease. It is interesting to note that the OLS estimate is positive, again indicating positive selection into the secondary segment of the labor market as discussed earlier.

What were the effects of the law on non-working childbearing-aged women? After the law, their relative likelihood of being hired has decreased. We observe that 
the reform led to a 4.8 percent (or 4.4 percentage points) increase in the relative odds of remaining out of employment. Notice that the OLS estimator is slightly smaller (but of the same sign), indicating a positive selection into employment, which in Spain is primarily employment under a fixed-term contract. Finally, the change in sign from OLS to FE estimator in the effect of the reform on the likelihood of transitioning from non-work to permanent is again consistent with the negative selection into the primary segment of the labor market that we observed earlier. Our preferred estimate reveals a negative albeit not significant effect of the law.

\section{Are Employers Able to Shift at Least Part of these Costs to Women by Lowering their}

\section{Wages?}

The 1999 Law has clearly increased the costs to employers in at least two different ways. First, the law has increased the worker's right to ask for a work-week reduction, which the employer is required to accept even if it goes against productive efficiency. Second, the law has increased the protection of part-time workers against dismissal. Table 4 explores whether employers are able to shift at least part of these costs to women by lowering their wages relative to comparable men. We estimate our preferred fixed-effect estimate, but using as LHS variable, $Y_{i t}$, the $\log$ of real hourly wage. Because we control for gender and post-law in this equation, the coefficient of interest, $\alpha_{2}$, indicates the effect of the law on the gender wage gap. The analysis is undertaken conditioning on employment status at $(t-1)$. Results from Table 4 reveal that employers were able to pass along at least part of the cost to childbearing-aged women through lower wages, with the amount passed to workers increasing with the precariousness of the job. While women's wages decreased by 1.15 percent (or 2.5 percentage points) relative to their male counterparts after the reform if the worker had a permanent contract at (t-1), the wage gap rose to 3.28 percent (or 6.6 percentage points) if the 
worker has a fixed-term contract at (t-1). Finally, a female individual entering employment after the reform had wages 5.30 percent (or 10.8 percentage points) lower than those of a male counterpart. ${ }^{13}$

Note that although only female permanent workers use the right granted by the law, employers also pass the associated costs to those under fixed-term contracts. This result is not surprising. If, as a result of the law, female workers have fewer chances of getting promoted or entering employment, they will compete more aggressively for the now more scarce jobs in both segments of the labor market, fixed-term included. Moreover, the lower willingness to hire by employers may be coupled with an increased supply if childbearing-aged women are now more willing to work in jobs that according to the law offer more possibilities to conciliate work and family life.

\section{Identification Threats}

In this section, we present several sensitivity checks regarding possible identification threats. First, Appendix Tables A1 and A2 (Panel A) restrict the control group to only childbearing-aged men who are not and have not been eligible. This is undertaken to address potential concerns that the control group could have been affected by the reform, since it included men with children under 7-years old (notice that we have already shown that despite being eligible, they are not affected by the law as there is no effect on their transitions into part-time work). Indeed, the estimates are similar to those present in the main text.

The main identification condition for the estimation of the policy effect is that, aside from the 1999 law, there have been no other shocks during or since the implementation of the law that might have affected the differential employment transitions (and wages) of childbearing-aged women relative to similar men (net of any

\footnotetext{
${ }^{13}$ In the last column, the pre-wage is the wage level of the last employment spell.
} 
underlying trends). Thus, another potential threat to our estimation strategy is that other policies affecting maternal employment were simultaneously implemented in Spain. There are two policies that may be of concern for our analysis. First, in 1997, the Spanish government attempted to reduce the incidence of fixed-term employment by reducing payroll taxes and dismissal costs for permanent contracts. This reform was extended in 2001. More specifically, the 1997 reform reduced unfair dismissal costs by around 25 percent and payroll taxes between 40 percent and 90 percent for newly signed permanent contracts after the second quarter of 1997 for workers under 30 years of age, over 45 years of age, the long-term unemployed, women under-represented in their occupations, and disabled workers. In addition, the reform reduced unfair dismissal costs by around 45 percent and payroll taxes by 50 percent for conversions of fixedterm into permanent contracts for all age groups. To the extent that these reforms generally apply to both men and women, any potential effects of the 1997 reform are "washed out" by our DiD methodology. To address the concern that payroll taxes for newly signed permanent contracts were lower for women under-represented in their occupations, we re-estimate the preferred specification using only those occupations in which women are not under-represented in Panel B of Appendix Tables A1 and A2, finding similar results to those presented in Table 3. This is consistent with the findings of Kugler et al., 2005, that the 1997 reform in Spain had little effect on women, and Blundell et al., 2004, who did not find effects of a similar policy on women in the United Kingdom.

The second policy that could threat our identification strategy is the 1997 and 2003 tax reforms, which altered the child deduction benefits. Tax deductions per children were small until 1997, yet were increased in 1998, and subsequently again in 1999 and 2003. In 2003, an additional tax credit of $€ 1,200$ a year was granted to 
working mothers with children younger than 3 -years old. ${ }^{14}$ It is unclear how these tax reforms affected the choice between working part-time, full-time, and non-employment. The tax deductions per children increased the after-tax income for households with children, which may have led to a reduction in hours worked (conditional on working) through an income effect (regardless of whether the increased deductions raised fertility or failed to do so). However, it is unclear whether this income effect is larger for men than women. In relative terms, the magnitude of the increase in disposable income from the 1999 and 2003 tax reforms were relatively small, ranging between 1.3 and 2.9 percent for low-bracket households (depending on the number of children), between 1.1 and 3.7 percent for middle-bracket ones, and between 0.8 and 3.7 percent for highbracket households for all mothers with children under 16 years (see Azmat and González 2010). Most importantly, they affected both fathers and mothers. Thus, unless men and women react differently to these tax reforms, again our identification strategy "washes out" the effects of these tax reforms. Nonetheless, in order to address this concern, we present results excluding parents from our analysis in Appendix Tables A.1 and A.2 (Panel C). The results are very similar to those obtained in Tables 3 and 4, both in terms of magnitude and statistical significance.

Finally, over the last decade Spain experienced a real estate boom that burst in 2008. Because such an industry disproportionately hires males over females, one may worry that our results could be driven by the real estate cycle. To explore this, we reconducted the analysis, dropping construction workers from our sample. Results shown in Appendix Table A1 and A2 (Panel D) are very similar to our preferred estimates.

\footnotetext{
${ }^{14}$ See Sánchez and Sánchez 2008, and Azmat and González 2010, for a thorough analysis on how these tax reforms affected fertility, labor force participation, and employment of married women. Both authors estimate the effects of the 2003 reform on maternal employment for mothers with children under 3 years old. Sánchez and Sánchez 2008, focus on the short-run effects while Azmat and González 2010, estimate long-run effects up until 6 years after the reform. Azmat and González 2010 find that the 2003 tax credit would have increased employment even more (up to $5 \%$ ) in the absence of the change in child deductions.
} 
Furthermore, we estimate the main results separately by groups of provinces according to the importance of the real estate boom in Appendix tables A6 and A7. In Panel A, we proxy the relevance of the real estate boom by whether the province is coastal or landlocked, since the boom was mainly in coastal areas. Alternatively, in Panel B we split provinces in two groups, those with a share of male employment in the construction sector between 1997 and 2007 above the average growth rate and those below. The results in Appendix Tables A6 and A7 indicate that overall the detrimental employment and wage effects of the law are not driven by the choice of province and seem to be unrelated to these proxies of construction activity.

\section{Additional Sensitivity Analysis}

Appendix Tables A3 and A4 present estimates of the coefficient of interest, $\alpha_{2}$, under alternative specifications. Panel A displays a within-individual FE differences-indifferences-in-differences (DiDiD) specification in which, in addition to young men and women, we include individuals older than 45. Accordingly, the addition of older workers enables us to control for any gender differences across time, not related to the law, obtaining the DiDiD estimator. This strategy is similar to that employed by Gruber, 1994; and Ruhm, 1998, among others. Both the wage and employment findings are similar to those obtained with our preferred specification. In addition, the DDD estimates suggest that the reform was even more detrimental for childbearing-aged women as it reduced their likelihood of remaining employed under a permanent contract, as well as their likelihood of being hired under a permanent contract.

Panels B to D of Tables A3 and A4 present alternative specifications of the DiD estimator. In Panel B, the region dummies are interacted with the post-1999 dummy and the woman dummy. In Panel C, year fixed-effects are introduced in the model. In 
Panel D, in addition to the linear time trend, we introduce a quadratic trend. Our estimates are robust to the different specifications.

Methodologically, our estimates rely on the differences-in-differences assumption that - in the absence of the law - the share of (permanent and fixed-term) employment (net of trends) of women would have remained constant relative to men. However, because this assumption is not testable, we proceed to carry out the following placebo test, shown in panel E of Appendix Tables A3 and A4. Accordingly, we estimate our preferred specification for a period in which no change in family-friendly law took place. Therefore, we use a pre-reform period for such estimates, excluding post-1999 data, and use a "fake" policy change in the year 1997. The only statistically significant coefficients (at the 10 percent level) on the policy interaction variable are a relative increase in the likelihood of being promoted from a fixed-term to a permanentcontract and a relative wage increase for those working at $(t-1)$. Besides these two estimates, the other coefficients are not statistically significant, supporting the assumption that our previous results on the effects of the 1999 law on child-bearing aged women were not spurious.

\section{Heterogeneity Effects}

\section{Short- Versus Longer-Run Effects}

It is plausible that the effects of this reform may have varied over time. For instance, it may well be that employers may have not immediately reacted to the law. However, as they experienced an increase in the number of mothers of small children requesting flexible work arrangements and subsequently gaining employment protection for several years (as long as their younger child is younger than 7 years old), employers may have become more cautious about hiring women or promoting them into 
permanent contracts overtime. An alternative scenario is that employers may have first reacted through lowering relative wages and subsequently realized that that was not sufficient to compensate for the higher expected costs of hiring childbearing-aged women. To explore this, we split the period after the implementation of the law in two sub-periods, one running from 2000 to 2004 and the other from 2005 to 2010 . Table 5 shows the effects of the law allowing for a differential effect before and after 2004, revealing that employers initially reacted to the reform by both substituting women away from (good) jobs and lowering their relative wages. Nonetheless, Table 5 also provides evidence that there is some learning as the employers substituted women away from jobs more so after 2004 than before. In this respect, the coefficients for the 20052010 period are generally larger in magnitude than those for the period from 2000 to 2004, and the difference between coefficients tends to be statistically significant at the $1 \%$ confidence interval.

Column 1 in Panel A from Table 5 shows that soon after the reform, employers are 30 percent (or 0.6 percentage points) more likely to let childbearing-aged working women "go" from permanent contracts relative to their male counterparts. After 2004, this relative odds increases by an additional 10 percent (or 0.2 percentage points). Similarly, we observe that after the reform, employers are 41 percent (or 5.3 percentage points) more likely to let childbearing-aged working women "go" from fixed-term contracts relative to their male counterparts, with this disadvantage widening by an additional 12 percent (or 1.8 percentage points) after 2004 .

Column 2 in Panel A shows that soon after the reform, employers are 25 percent (or 1.5 percentage points) less likely to promote childbearing-aged women from fixedterm to permanent contracts relative to their male counterparts. After 2004, this relative odds decreases by 8 percent (or 0.5 percentage points), although the difference between 
the pre- and post-2004 effects is not statistically significant at the $1 \%$ level. While we do not observe a negative employment effect among women with a permanent contract at $(t-1)$, column 1 from Panel B from Table 5 does reveal that they receive 1.25 percent lower wages after 1999 than their male counterparts (although this effect does not increase after 2004). Consistent with earlier results, we find that the relative wage loss is greater for women with a fixed-term contract, as they are more vulnerable (2.98 percent before 2004), and that the wage gap increases after 2004 (3.78 percent after 2004).

Finally, column 3 in panel A shows that the likelihood of being hired also worsens over time for childbearing-aged women relative to men. For instance, while women are 6.6 percent (or 5 percentage points) less likely to enter employment after 1999 than their male counterparts, after 2004 their relative likelihood of entering employment is 9 percent (or 6.9 percentage points) lower than that of men. Women entering the labor market also receive 4.32 percent lower relative wages than their male counterparts after the reform (although we find no evidence that the gap widens after 2004), as shown in Panel B from Table 5.

\section{Other Heterogeneity Effects}

In order to widen our understanding of the effects of this reform, we proceed to explore whether there are heterogeneity effects (shown in Tables 6 and 7) by performing three types of analyses. First, we ask whether the negative employment and wage effects of the law are driven by women's eligibility. It is possible that employers only substitute away from eligible women because these are the women affected by the law at the time of employment. When analysis is undertaken as to whether women are eligible or not (namely, whether or not they have children under 7-years old), we observe that the unintended effects of the law on women's employment and wages relative to those of 
men are driven by both groups, not only the eligible women (see Panel A). Thus, employers also substituted away from women who are at risk of being eligible.

Second, we analyze whether the negative employment and wage effects vary according to whether the job is blue- or white-collar. While one would expect the employers' costs to increase more for white-collar workers, given their tasks may be more difficult to split and share than for blue-collar workers, the firm-specific human capital may be larger among white-collar jobs, thus giving more leverage to these workers. On the other hand, if white-collar workers do not use the rights granted by the new law, then we would not expect to observe much of a penalty on this group. Panel B shows the results for blue- versus white-collar jobs, highlighting that the effects of the reform on employment transitions are driven by blue-collar jobs. The coefficients are the same size and significance as those found for the whole group of workers. In contrast, the effects of the reform on employment transitions for white-collar jobs are not statistically significant and the size of the coefficients tends to be much smaller (and sometimes with different sign). Indeed, Appendix Table A5 indicates that eligible bluecollar workers use the rights granted by the law, but white-collar workers do not. This is consistent with employers discriminating against those workers most likely to use the right to work part-time. When we analyze whether employers are able to pass along the higher costs to employees through lower wages, we observe that they indeed do so both for blue- and white-collar jobs, and are able to pass along more of the costs if the worker is under a more precarious contract (shown in Panel B from Table 7). For instance, we find that blue-collar childbearing-aged women receive 2.19 percent (or 1.21 percent) lower wages than their male counterparts after the reform if they were working under a fixed-term (permanent contract). For women in white-collar jobs, Panel B from Table 6 does reveal that employers are able to shift at least part of the 
costs for this group, by 1.26 to 2.85 percent lower wages relative to childbearing-aged men.

Panel C from Tables 6 and 7 present results by employers' size. We would expect the penalties to be greater in smaller as opposed to larger firms, given that smaller ones have less flexibility to adjust to their employees' change of work-week requirements. Indeed, we find that the employment results are driven by firms with 10 employees or less. After the reform, small firms are 30 and 57 percent more likely to let childbearing-aged women go (or 2.4 and 0.4 percentage points) from fixed-term and permanent jobs. Similarly, they are less likely to promote women into permanent contracts by 65 percent (or 3.2 percentage points), which is greater than the reduction observed in large firms of 47 percent (or 2.4 percentage points). However, the wage adjustment to the detriment of women is observed in both small and large firms, as shown in Table 7 Panel C.

\section{Conclusion}

This paper analyzes the employment effects of the Spanish 1999 law granting workweek reduction rights to mothers of small children and protecting them against dismissal. Our main finding is that this law led to both the substitution of childbearingaged women away from (good) jobs and a decrease in their relative wages.

Studying the impact of this reform on childbearing-aged women provides a good illustration of the potential benefits and drawbacks of targeting employment protection on specific groups of workers. On the one hand, this law encourages the primary caregiver (usually mothers) to remain employed in part-time work. On the other hand, firms also hire fewer childbearing-aged women all together, or limit childbearing-aged 
female workers to jobs in which the effects of such law are weaker or less prolonged, thereby increasing gender segregation.

Our paper contributes to the literature on the effects of protective measures for female workers in the following ways. First, using a quasi-experimental approach, our empirical analysis provides convincing evidence on the effects of a family-friendly law that entitles workers with young children to work part-time--blending the literature on flexible work arrangements and parental leave. This parental benefit is becoming increasingly popular in industrialized countries, which renders our analysis timely and policy-relevant. Second, even though our analysis shows that employers are able to pass some of the costs of this policy to workers in the form of lower wages, our findings that employers substitute childbearing-aged women away from (good) jobs suggest that they are unable to pass all of the costs to the employees. Third, our study provides strong evidence that entitlements allowing substantial reduction of work schedules cause employers to limit at-risk women to jobs in which such law is not binding, such as jobs under fixed-term contracts, thus further increasing gender fixed-term contract segregation. Subgroup analysis is consistent with employers adjusting more among blue-collar jobs and more vulnerable contracts. Furthermore, small firms seem to be the most negatively affected by the new regulations, as well as those who have reacted more strongly. In addition, there is evidence that employers learn and become more wary of hiring women over time.

\section{REFERENCES}

Albrecht, J., P. Edin, M. Sundström, and S. Vroman. 1998. "Career Interruptions and Subsequent Earnings: A Reexamination Using Swedish Data," Journal of Human Resources, 34 (1998), 294-311. 
Amuedo-Dorantes C. 2002. "Work Safety in the Context of Temporary Employment: The Spanish Experience," Industrial and Labor Relations Review, 2002, 55(2): 262-72.

Amuedo-Dorantes, C., and Serrano-Padial. 2007. "Wage Growth Implications of Fixed-Term Employment: An Analysis by Contract Duration and Job Mobility." Labour Economics.

Azmat, G. and González, L. 2010. "Targeting fertility and female participation through the income tax," Labour Economics, Elsevier, vol. 17(3), pages 487-502, June.

Baum, C. 2003. "The Effects of Maternity Leave Legislation on Mothers' Labor Supply After Childbirth." Southern Economic Journal 69(4), 772-799.

Beard, K. M., and Edwards, J. R. 1995. Employees at risk: Contingent work and the psychological experience of contingent workers. In C. L. Cooper \& D. M. Rousseau (Eds.), Trends in organizational behavior (vol. 2, pp. 109-126). New York: Wiley.

Bentolila S. J. J. Dolado, and J.F. Jimeno. 2008. "Two-Tier Employment Protection Reforms: The Spanish Experience." CESifo DICE Report 4/2008.

Engellandt, A. and R. Riphahn. 2005. "Temporary contracts and employee effort," Labour Economics, Elsevier, vol. 12(3), pages 281-299, June.

Estrada, A., M. Izquierdo, and A. Lacuesta. 2009. "Labor Market and Unemployment Growth in Spain.” Economic Bulletin Banco de España July 2009.

Fernández-Kranz, D., and N. Rodríguez-Planas. 2011. "The Part-Time Penalty in a Segmented Labor Market." Labour Economics, Volume 18, 591-606, 2011.

Fitzenberger B., K. Sommerfeld, S. Steffes. 2012. " Causal e ${ }^{\circledR e c t s}$ on employment after ${ }^{-}$rst birth-A dynamic treatment approach."mimeo.

Fouarge D. and C. Baaijens. 2009. "Job Mobility and hours of work: the effect of Dutch legislation," Research Memoranda 004, Maastricht : ROA, Research Centre for Education and the Labour Market.

Gornick J., and Hegewisch, A. 2011 "The Impact of Work-Family Policies on Women's Employment: A Review of Research from OECD Countries." Community, Work \& Family, 14(2): 119-138.

Gruber, J. 1994. "The Incidence of mandated Maternity Benefits" American Economic Review 84: 622-641.

Güell, M. and B. Petrongolo. 2007. "How Binding are Legal Limits?: Transitions from Temporary to Permanent Work in Spain", Labour Economics 14, 153-183.

Ichino, A. and R. Riphan. 2005. "The Effect of Employment Protection on Worker Effort. A comparison of absenteeism during and after probation". Journal of the European Economic Association, March, 3(1), 120-43.

Jimeno, J. F., and L. Toharia. 1996. "Effort absenteeism, and fixed-term employment contracts." Revista Española de Economía, vol. 13(1), pp. 105-19.

Klerman, J. and A. Leibowitz. 1997. "Labor Supply Effects of State Maternity Leave Legislation", in: Blau, F. D. and R. G. Ehrenberg (eds.), Gender and Family Issues in the Workplace. New York: Russell Sage Foundation, 65-85. 
Klerman, J. and A. Leibowitz. 1999. "Job Continuity Among New Mothers." Demography, 36, 145-155.

Kugler A., Hernanz V., and J. Jimeno. 2005. "Employment Consequences of Restrictive Permanent Contracts : Evidence from Spanish Labor Market Reforms." CEPR Discussion Paper No. 3724, May 2003

Lalive R. and J. Zweimüller. 2009. "Does Parental Leave Affect Fertility and Return to Work?" Evidence from a True Natural Experiment" The Quarterly Journal of Economics, August 2009.

Larrañaga, I., B. Arregui and J. Arpal. 2004: «Reproductive or domestic work», Gaceta Sanitaria, 18, supl.1, 31-37.

Manning, A. and B. Petrongolo. 2008. "The Part-Time Pay Penalty for Women in Britain." The Economic Journal, 118: F28-51.

Marí-Klose, P, M. Marí-Klose, E. Vaquera, and S. Ageseanu Cunningham. 2010. "Childhood and the Future". New realities, new challenges. Barcelona: Obra Social de la Caixa

Meyer, B. D. 1995. "Natural and quasi-experiments in economics", Journal of Business and Economic Statistics, Vol. 13: 151-161.

Munz, S., 2004. Flexibility of working hours and job mobility in Germany: the role of the part-time and fixed-term act (Ifo, Munich).

New York Times, 19 January 2013. "Sunday Dialogue: Flexible Hours" Letters to the Editor.

New York Times, 14 June 2013. "The Unspoken Stigma of Workplace Flexibility" by Tara Siegel Bernard.

Olsson, Martin, 2009. "Employment protection and sickness absence," Labour Economics, Elsevier, vol. 16(2), pages 208-214, April.

Pfau-Effinger, B. 2006. "Cultures of Childhood and the Relationship of Care and Employment in European Welfare States." In Children, Changing Families and Welfare States, ed. J. Lewis. Cheltenham, UK: Edward Elgar.

Ruhm, Ch. J. 1998. "The Economic Consequences of Parental Levae Mandates: Lessons from Europe" Quarterly Journal of Economics 113: 285-317.

Sánchez-Mangas, R. and Sánchez-Marcos, V. 2008. "Balancing Family and Work: the Effect of Cash Benefits for Working Mothers", Labour Economics, 15 (6), 1127 1142 .

Schönberg, Uta, and Johannes Ludsteck, "Maternity Leave Legislation, Female Labor Supply, and the Family Wage Gap," forthcoming in Journal of Labor Economics.

Waldfogel, J. 1998. "The Family Gap for Young Women in the United States and in Britain: Can Maternity Leave Make a Difference? Journal of Labor Economics 16: 505-545 
Waldfogel, J. 1999. "The Impact of the Family and Medical Leave Act" Journal of Policy Analysis and Management 118: 281-302

Zveglich, Jr., J.E. and Y. van der Meulen Rodgers. 2003. "The Impact of Protective Measures for Female Workers" Journal of Labor Economics 21: 533-555. 
Figure 1. Employment Outcomes of Childbearing-Aged Women and Childbearing Aged Men, 1996-2010
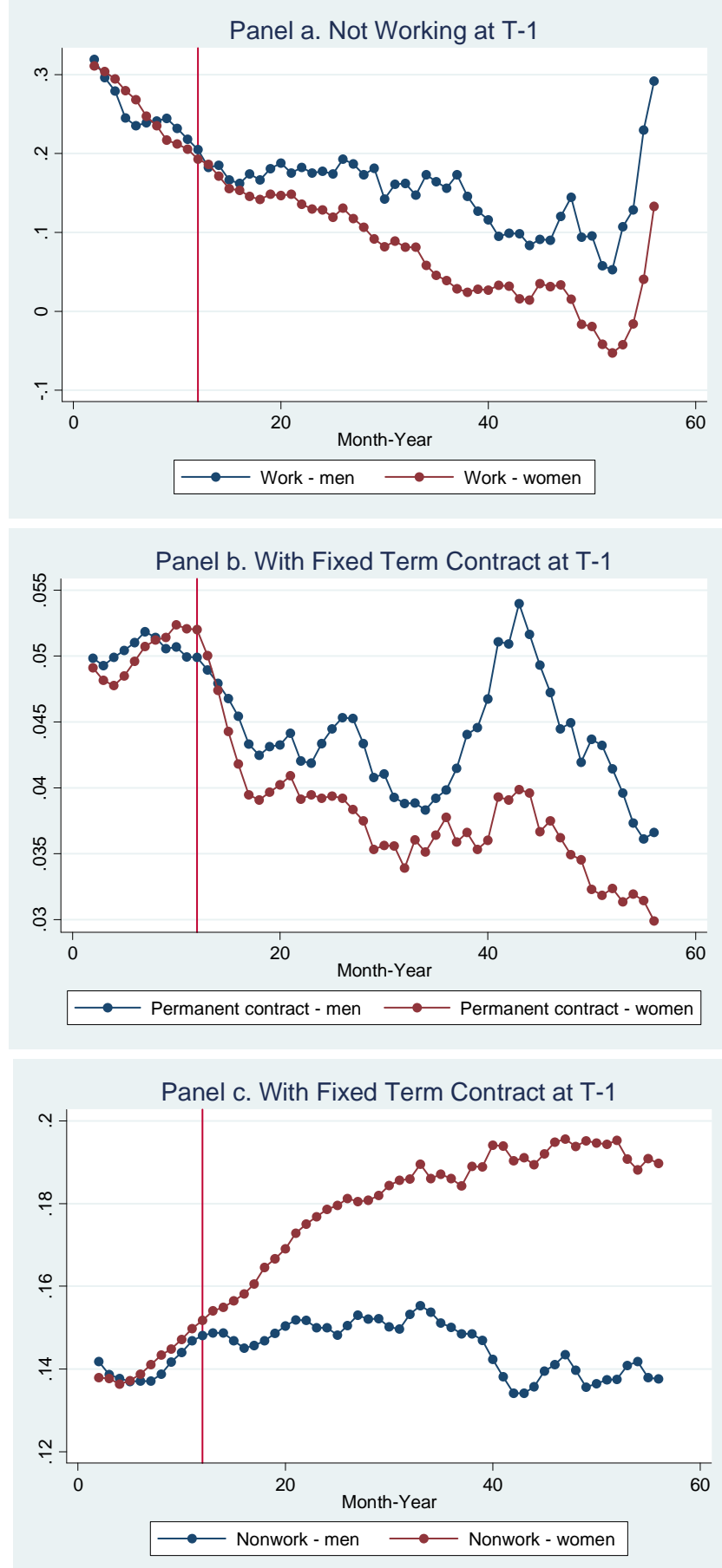

Note: Moving averages (forward) using quarterly data. The vertical line separates the pre-1999 and the post-1999 periods. The figures show the detrended probabilities of different work status at time $t$ conditional on the work status at time t-1 (one quarter before). The detrended probabilities come from regressions that control for age, region and a linear time trend. When the work status being considered is working under a permanent contract at time t, the model is conditioned to being working at $\mathrm{t}$. 
Table 1. Was the Law Effective?

\begin{tabular}{|c|c|c|}
\hline & \multicolumn{2}{|c|}{$\begin{array}{l}\text { Panel A: Treatment: Women with Children } 0-6^{\gamma} \\
\text { (Control group is women with children } 7-12)^{\gamma}\end{array}$} \\
\hline & $\begin{array}{c}\text { (1) } \\
\text { PERMANENT at t-1 }\end{array}$ & $\begin{array}{c}\text { (2) } \\
\text { FIXED-TERM at t-1 }\end{array}$ \\
\hline $\begin{array}{l}\text { PART-TIME at } t \\
\text { (being Full-time at } t-1 \text { ) }\end{array}$ & $\begin{array}{l}.004^{* *} \\
(.002)\end{array}$ & $\begin{array}{l}-.012 \\
(.021)\end{array}$ \\
\hline Pre-99 mean & .003 & .044 \\
\hline $\begin{array}{l}\text { PART-TIME at } t \\
\text { (being Full-time at } t-1 \\
\text { and conditional on being on the same firm) }\end{array}$ & $\begin{array}{c}.006^{* * *} \\
(.002)\end{array}$ & $\begin{array}{l}-.011 \\
(.018)\end{array}$ \\
\hline Pre-99 mean & .003 & .041 \\
\hline $\begin{array}{l}\text { PART-TIME at } t \\
\text { (being Full-time at } t-1 \\
\text { and conditional on changing firm) }\end{array}$ & $\begin{array}{l}-.145^{*} \\
(.084)\end{array}$ & $\begin{array}{l}.050 \\
(.267)\end{array}$ \\
\hline Pre-99 mean probability & .081 & .166 \\
\hline N. of observations & 129,220 & 60,392 \\
\hline \multirow[t]{3}{*}{ N. of individuals } & 9,007 & 8,166 \\
\hline & \multicolumn{2}{|c|}{$\begin{array}{l}\text { Panel B: Treatment: Men with Children } 0-6^{\gamma} \\
\text { (Control group is Men with children } 7-12 \text { ) }\end{array}$} \\
\hline & $\begin{array}{c}\text { (1) } \\
\text { PERMANENT at } t-1\end{array}$ & $\begin{array}{c}\text { (2) } \\
\text { FIXED-TERM at } t-1\end{array}$ \\
\hline $\begin{array}{l}\text { PART-TIME at t } \\
\text { (being Full-time at t-1) }\end{array}$ & $\begin{array}{r}-.000 \\
(.001) \\
\end{array}$ & $\begin{array}{c}.004 \\
(.007)\end{array}$ \\
\hline Pre-99 mean & .000 & .000 \\
\hline $\begin{array}{l}\text { PART-TIME at } t \\
\text { (being Full-time at } t-1 \text { and conditional on } \\
\text { being on the same firm) }\end{array}$ & $\begin{array}{l}-.000 \\
(.001)\end{array}$ & $\begin{array}{l}-.004 \\
(.006)\end{array}$ \\
\hline Pre-99 mean & .000 & .000 \\
\hline $\begin{array}{l}\text { PART-TIME at } t \\
\text { (being Full-time at } t-1 \\
\text { and conditional on changing firm) }\end{array}$ & $\begin{array}{l}-.022 \\
(.094)\end{array}$ & $\begin{array}{c}.030 \\
(.083)\end{array}$ \\
\hline Pre-99 mean probability & .025 & .035 \\
\hline N. of observations & 108,211 & 29,334 \\
\hline \multirow[t]{3}{*}{ N. of individuals } & 5,764 & 3,403 \\
\hline & \multicolumn{2}{|c|}{$\begin{array}{l}\text { Panel C: Placebo Test (Mothers) } \\
\text { 1996-97 versus 1998-99 }\end{array}$} \\
\hline & $\begin{array}{c}\text { (1) } \\
\text { PERMANENT at } \mathrm{t}-1\end{array}$ & $\begin{array}{c}\text { (2) } \\
\text { FIXED-TERM at t-1 }\end{array}$ \\
\hline $\begin{array}{l}\text { PART-TIME at } t \\
\text { (being Full-time at } t-1 \text { ) }\end{array}$ & $\begin{array}{c}.000 \\
(.005)\end{array}$ & $\begin{array}{l}.037 \\
(.044)\end{array}$ \\
\hline Pre-99 mean probability & .001 & .035 \\
\hline $\begin{array}{l}\text { PART-TIME at } t \\
\text { (being Full-time at } t-1 \\
\text { and conditional on being on the same firm) }\end{array}$ & $\begin{array}{l}-.003 \\
(.004)\end{array}$ & $\begin{array}{c}.021 \\
(.040)\end{array}$ \\
\hline Pre-99 mean probability & .001 & .035 \\
\hline $\begin{array}{l}\text { PART-TIME at } \mathrm{t} \\
\text { (being Full-time at } \mathrm{t}-1 \\
\text { and conditional on changing firm) } ¥\end{array}$ & .. & .. \\
\hline Pre-99 mean probability & .. & .. \\
\hline N. of observations & 9,656 & 3,832 \\
\hline N. of individuals & 1,059 & 773 \\
\hline
\end{tabular}

${ }^{\gamma}$ Note: Numbers in parentheses are robust standard errors allowing for intra cluster (individual) correlation.

*** Significant at the $1 \%$ level. ${ }^{* *}$ Significant at the $5 \%$ level. * Significant at the $10 \%$ level. All models control for education, education interacted with being a woman, number of children and number of children interacted with being a woman, age, age squared, region dummies, the regional unemployment rate, a linear time trend, a linear time trend interacted with being a woman, woman dummy, a post-1999 dummy, and the interaction between these two variables. The regressions where the dependent variable is working under a PERMANENT contract at $t$, condition on being working at $t$. $¥$ Values not reported due to insufficient observations to run the regressions. 
Table 2. Descriptive Statistics for childbearing aged women

\begin{tabular}{|c|c|c|c|c|c|c|}
\hline & \multicolumn{6}{|c|}{ Pre-2000 } \\
\hline & \multirow{2}{*}{\multicolumn{2}{|c|}{$\begin{array}{c}(1) \\
\text { PERMANENT at t-1 }\end{array}$}} & \multirow{2}{*}{\multicolumn{2}{|c|}{$\begin{array}{c}(2) \\
\text { FIXED-TERM at t-1 }\end{array}$}} & \multirow{2}{*}{\multicolumn{2}{|c|}{$\begin{array}{c}(3) \\
\text { NON-WORK at t-1 }\end{array}$}} \\
\hline & & & & & & \\
\hline $\begin{array}{l}\text { Probability of } \\
\text { PERMANENT at } t\end{array}$ & .96 & .95 & .05 & .06 & .02 & .02 \\
\hline $\begin{array}{l}\text { With less than } \\
\text { secondary } \\
\text { education }\end{array}$ & 45.56 & 37.53 & 60.01 & 44.41 & 54.44 & 48.77 \\
\hline $\begin{array}{l}\text { With secondary } \\
\text { education }\end{array}$ & 25.96 & 30.66 & 18.81 & 23.13 & 21.16 & 22.12 \\
\hline White-collar at t & 17.82 & 16.35 & 20.89 & 15.58 & 7.70 & 6.61 \\
\hline Ln hourly wage at $t$ & 2.26 & 2.13 & 2.06 & 1.95 & 2.00 & 1.97 \\
\hline Without children & 79.62 & 75.67 & 92.90 & 85.49 & 94.05 & 78.95 \\
\hline Age & 30.34 & 30.18 & 24.91 & 26.58 & 24.32 & 26.33 \\
\hline $\begin{array}{l}\text { Unemployment } \\
\text { rate }\end{array}$ & 13.62 & 13.58 & 11.85 & 12.28 & 12.23 & 12.00 \\
\hline
\end{tabular}

Note: All mean differences between men and women are statistically different from zero at the $1 \%$ confidence interval.

Table 3. Effects of the Law on Employment Transitions on Childbearing-Aged Women

(Control group: Childbearing-Aged Men)

\begin{tabular}{|c|c|c|c|c|c|c|}
\hline & \multicolumn{3}{|c|}{ Panel A: DiD Individual FE model } & \multicolumn{3}{|c|}{ Panel B: DiD OLS } \\
\hline & $\begin{array}{c}\text { (1) } \\
\text { PERMANENT } \\
\text { at t-1 }\end{array}$ & $\begin{array}{c}\text { (2) } \\
\text { FIXED-TERM } \\
\text { at t-1 }\end{array}$ & $\begin{array}{c}\text { (3) } \\
\text { NON-WORK } \\
\text { at t-1 }\end{array}$ & $\begin{array}{c}\text { (1) } \\
\text { PERMANENT } \\
\text { at t-1 }\end{array}$ & $\begin{array}{c}(2) \\
\text { FIXED- } \\
\text { TERM at t-1 }\end{array}$ & $\begin{array}{c}\text { (3) } \\
\text { NON-WORK } \\
\text { at t-1 }\end{array}$ \\
\hline $\begin{array}{l}\text { 1. PERMANENT } \\
\text { at } \mathrm{t}\end{array}$ & $\begin{array}{l}-.000 \\
(.001)\end{array}$ & $\begin{array}{c}-.017 * * * \\
(.004)\end{array}$ & $\begin{array}{l}-.025 \\
(.019)\end{array}$ & $\begin{array}{l}-.000 \\
(.001)\end{array}$ & $\begin{array}{l}.011^{* * *} \\
(.002)\end{array}$ & $\begin{array}{c}.047^{* * *} \\
(.014)\end{array}$ \\
\hline $\begin{array}{l}\text { Pre-99 mean } \\
\text { probability }\end{array}$ & .997 & .046 & $.160^{¥}$ & .997 & .046 & $.160^{¥}$ \\
\hline $\begin{array}{l}\text { 2. NON-WORK } \\
\text { at t }\end{array}$ & $\begin{array}{c}.005^{* * *} \\
(.001)\end{array}$ & $\begin{array}{c}.047^{* * *} \\
(.005)\end{array}$ & $\begin{array}{c}.044^{* * *} \\
(.006)\end{array}$ & $\begin{array}{c}.008 * * * \\
(.001)\end{array}$ & $\begin{array}{c}.031 * * * \\
(.004)\end{array}$ & $\begin{array}{c}.037 * * * \\
(.004)\end{array}$ \\
\hline $\begin{array}{l}\text { Pre-99 mean } \\
\text { probability }\end{array}$ & .011 & .117 & .910 & .011 & .117 & .910 \\
\hline N. obser. & $1,226,822$ & $1,014,089$ & 738,253 & $1,226,822$ & $1,014,089$ & 738,253 \\
\hline N. individuals & 69,233 & 95,794 & 77,026 & 69,233 & 95,794 & 77,026 \\
\hline
\end{tabular}

Note. Numbers in parentheses are robust standard errors allowing for intra cluster (individual) correlation.

$* * *$ Significant at the $1 \%$ level. ${ }^{* *}$ Significant at the $5 \%$ level. ${ }^{*}$ Significant at the $10 \%$ level. Childbearing-aged women (men) are women (men) aged 23 to 44 . All models control for education, education interacted with being a woman, number of children and number of children interacted with being a woman, age, age squared, region dummies, the regional unemployment rate, a linear time trend, a linear time trend interacted with being a woman, woman dummy, a post-1999 dummy, and the interaction between these two variables. In the regressions where we estimate the probability of a transition into PERMANENT employment we condition on being employed at $t$ and therefore the coefficient indicates the probability of staying or transitioning into permanent employment as opposed to fixed-term employment. ${ }^{¥}$ The seemingly large value in this transition is explained by the fact that in row 1 we condition on being employed at time $t$, therefore this is the estimated probability of going from non-work into permanent employment as opposed to fixed-term employment. 
Table 4. Effects of the Law on Childbearing-Aged Women's Wages

(Control group: Childbearing-Aged Men)

Individual FE model

Controlling for work status at $\mathrm{t}-1$

\begin{tabular}{|c|c|c|c|}
\hline & \multicolumn{3}{|c|}{ Controlling for work status at $\mathrm{t}-1$} \\
\hline & $\begin{array}{c}\text { (1) } \\
\text { PERMANENT at t-1 }\end{array}$ & $\begin{array}{c}\text { (2) } \\
\text { FIXED-TERM at t-1 }\end{array}$ & $\begin{array}{c}\text { (3) } \\
\text { NON-WORK at t-1 }\end{array}$ \\
\hline $\begin{array}{l}\text { Change in the } \\
\text { gender wage } \\
\text { gap }\end{array}$ & $\begin{array}{l}-.025^{* * *} \\
(.004)\end{array}$ & $\begin{array}{c}-.066 * * * \\
(.010)\end{array}$ & $\begin{array}{c}-.108 * * * \\
(.023)\end{array}$ \\
\hline $\begin{array}{l}\text { Pre } 1999 \\
\text { average } \\
\text { treated }\end{array}$ & 2.164 & 2.011 & 2.038 \\
\hline N. obs. & $1,226,822$ & $1,014,089$ & 738,253 \\
\hline N. individuals & 69,233 & 95,794 & 77,026 \\
\hline
\end{tabular}

Note. Numbers between parentheses are robust standard errors, allowing for intra cluster (individual) correlation. *** Significant at the $1 \%$ level. ${ }^{* *}$ Significant at the $5 \%$ level. * Significant at the $10 \%$ level. The change in the gender wage gap captures the change in the gender wage gap after the reform relative to the pre-reform period, and after controlling for the covariates. Childbearing aged women (men) are women (men) aged 23 to 44 . All models control for education, education interacted with being a woman, number of children and number of children interacted with being a woman, age, age squared, region dummies, the regional unemployment rate, a linear time trend, a linear time trend interacted with being a woman, woman dummy, a post-1999 dummy, and the interaction between these two variables.

Table 5. Is There Learning?

(Control group: Childbearing-Aged Men)

Individual FE model

\begin{tabular}{|c|c|c|c|}
\hline & \multicolumn{3}{|c|}{ Panel A: Effects on Employment Transitions } \\
\hline & (1) & (2) & (3) \\
\hline & PERMANENT at $\mathrm{t}-1$ & FIXED-TERM at t-1 & NON-WORK at t-1 \\
\hline \multicolumn{4}{|c|}{ PERMANENT at $t$} \\
\hline $2000-2004$ & $\begin{array}{l}-.000 \\
(.000)\end{array}$ & $\begin{array}{l}-.015^{* * *} \\
(.004)\end{array}$ & $\begin{array}{l}-.023 \\
(.020)\end{array}$ \\
\hline $2005-2010$ & $\begin{array}{l}.000 \\
(.001)\end{array}$ & $\begin{array}{c}-.010^{* *} \\
(.005)\end{array}$ & $\begin{array}{l}-.019 \\
(.021)\end{array}$ \\
\hline \multicolumn{4}{|c|}{ NON-WORK at t } \\
\hline $2000-2004$ & $\begin{array}{l}.006 * * * \\
(.001)\end{array}$ & $\begin{array}{l}.053^{* * *} \\
(.005)\end{array}$ & $\begin{array}{l}.050 * * * \\
(.006)\end{array}$ \\
\hline $2005-2010$ & $\begin{array}{c}.008^{* * *} * \\
(.001)\end{array}$ & 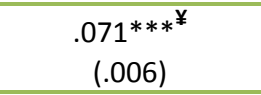 & $\begin{array}{c}.069 * * *^{*} \\
(.008)\end{array}$ \\
\hline N. obs. & $1,226,822$ & $1,014,089$ & 738,253 \\
\hline \multirow[t]{3}{*}{ N. individuals } & 69,233 & 95,794 & 77,026 \\
\hline & \multicolumn{3}{|c|}{ Panel B: Effects on Wages } \\
\hline & $\begin{array}{c}\text { (1) } \\
\text { PERMANENT at t-1 }\end{array}$ & $\begin{array}{c}\text { (2) } \\
\text { FIXED-TERM at } t-1\end{array}$ & $\begin{array}{c}\text { (3) } \\
\text { NON-WORK at t-1 }\end{array}$ \\
\hline $2000-2004$ & $\begin{array}{c}-.027^{* * *} \\
(.005)\end{array}$ & $\begin{array}{c}-.060 * * * \\
(.011) \\
\end{array}$ & $\begin{array}{c}-.088 * * * \\
(.027) \\
\end{array}$ \\
\hline $2005-2010$ & $\begin{array}{c}-.026 * * * \\
(.006)\end{array}$ & $\begin{array}{c}-.076^{* * * *} \\
(.012)\end{array}$ & $\begin{array}{c}-.097 * * * \\
(.030)\end{array}$ \\
\hline N. obs. & $1,226,822$ & $1,014,089$ & 738,253 \\
\hline N. individuals & 69,233 & 95,794 & 77,026 \\
\hline
\end{tabular}

Note. Numbers between parentheses are robust standard errors, allowing for intra cluster (individual) correlation. *** Significant at the $1 \%$ level. ** Significant at the $5 \%$ level. * Significant at the $10 \%$ level. $2000-2004$ indicates the effect of the Law for years 2000 to $2004 .{ }^{*}$ Indicates that the difference between the 2000-2004 and the 2005-2010 effects is statistically significant at the 1\% level. Childbearing aged women (men) are women (men) aged 23 to 44. All models control for education, education interacted with being a woman, number of children and number of children interacted with being a woman, age, age squared, region dummies, the regional unemployment rate, a linear time trend, a linear time trend interacted with being a woman, woman dummy, a 2000-2004 dummy, and a 2005-2010 dummy, and the interaction between these two variables and the woman dummy. 
Table 6. Heterogeneity Analysis

The Effect of the 1999 Law on Childbearing-Aged Women's Employment Outcomes (Control group is childbearing aged men)

Individual FE Model

\begin{tabular}{|c|c|c|c|c|c|c|}
\hline & \multicolumn{6}{|c|}{ Panel A: By eligibility status } \\
\hline & \multicolumn{3}{|c|}{ Eligible Women } & \multicolumn{3}{|c|}{ Non-Eligible Women } \\
\hline & $\begin{array}{c}\text { (1) } \\
\text { PERMANENT } \\
\text { at t-1 }\end{array}$ & $\begin{array}{c}\text { (2) } \\
\text { FIXED-TERM } \\
\text { at } \mathrm{t}-1\end{array}$ & $\begin{array}{c}\text { (3) } \\
\text { NON-WORK } \\
\text { at t-1 }\end{array}$ & $\begin{array}{c}\text { (1) } \\
\text { PERMANENT } \\
\text { at t-1 }\end{array}$ & $\begin{array}{c}\text { (2) } \\
\text { FIXED-TERM } \\
\text { at } \mathrm{t}-1\end{array}$ & $\begin{array}{c}(3) \\
\text { NON-WORK } \\
\text { at t-1 }\end{array}$ \\
\hline $\begin{array}{l}\text { PERMANENT } \\
\text { at } \mathrm{t}\end{array}$ & $\begin{array}{l}-.000 \\
(.001)\end{array}$ & $\begin{array}{c}-.023 * * * \\
(.007)\end{array}$ & $\begin{array}{c}-.068^{*} \\
(.036)\end{array}$ & $\begin{array}{l}-.000 \\
(.001)\end{array}$ & $\begin{array}{c}-.014 * * * \\
(.005)\end{array}$ & $\begin{array}{l}-.020 \\
(.024)\end{array}$ \\
\hline $\begin{array}{l}\text { Pre-99 mean } \\
\text { probability }\end{array}$ & .997 & .047 & .172 & .997 & .045 & .150 \\
\hline $\begin{array}{l}\text { NON-WORK } \\
\text { at } \mathrm{t}\end{array}$ & $\begin{array}{l}.007^{* * *} \\
(.001)\end{array}$ & $\begin{array}{c}.048 * * * \\
(.008)\end{array}$ & $\begin{array}{l}.049 * * * \\
(.011)\end{array}$ & $\begin{array}{l}.006 * * * \\
(.001)\end{array}$ & $\begin{array}{c}.048 * * * \\
(.007)\end{array}$ & $\begin{array}{c}.044 * * * \\
(.007)\end{array}$ \\
\hline $\begin{array}{l}\text { Pre-99 mean } \\
\text { probability }\end{array}$ & .010 & .101 & .916 & .012 & .131 & .903 \\
\hline N. observ. & 395,568 & 192,270 & 149,983 & 831,254 & 821,819 & 588,270 \\
\hline \multirow[t]{4}{*}{ N. individuals } & 15,125 & 15,940 & 12,808 & 54,108 & 79,854 & 64,218 \\
\hline & \multicolumn{6}{|c|}{ Panel B: By occupation } \\
\hline & \multicolumn{3}{|c|}{ White-Collar } & \multicolumn{3}{|c|}{ Blue-Collar } \\
\hline & $\begin{array}{c}\text { (1) } \\
\text { PERMANENT } \\
\text { at t-1 }\end{array}$ & $\begin{array}{c}\text { (2) } \\
\text { FIXED-TERM } \\
\text { at t-1 }\end{array}$ & $\begin{array}{c}\text { (3) } \\
\text { NON-WORK } \\
\text { at t-1 }\end{array}$ & $\begin{array}{c}\text { (1) } \\
\text { PERMANENT } \\
\text { at t-1 }\end{array}$ & $\begin{array}{c}\text { (2) } \\
\text { FIXED-TERM } \\
\text { at } \mathrm{t}-1\end{array}$ & $\begin{array}{c}\text { (3) } \\
\text { NON-WORK } \\
\text { at t-1 }\end{array}$ \\
\hline $\begin{array}{l}\text { PERMANENT } \\
\text { at } \mathrm{t}\end{array}$ & $\begin{array}{l}.002 \\
(.001)\end{array}$ & $\begin{array}{l}-.009 \\
(.012)\end{array}$ & $\begin{array}{l}.016 \\
(.070)\end{array}$ & $\begin{array}{l}-.000 \\
(.001)\end{array}$ & $\begin{array}{c}-.016^{* * *} \\
(.004)\end{array}$ & $\begin{array}{l}-.020 \\
(.021)\end{array}$ \\
\hline $\begin{array}{l}\text { Pre-99 mean } \\
\text { probability }\end{array}$ & .997 & .053 & .175 & .997 & .052 & .158 \\
\hline $\begin{array}{l}\text { NON-WORK } \\
\text { at } \mathrm{t}\end{array}$ & $\begin{array}{l}-.000 \\
(.001)\end{array}$ & $\begin{array}{l}-.002 \\
(.009)\end{array}$ & $\begin{array}{l}-.016 \\
(.027)\end{array}$ & $\begin{array}{l}.006 * * * \\
(.001)\end{array}$ & $\begin{array}{l}.051^{* * *} \\
(.006)\end{array}$ & $\begin{array}{c}.045^{* * *} \\
(.006)\end{array}$ \\
\hline $\begin{array}{l}\text { Pre-99 mean } \\
\text { probability }\end{array}$ & .006 & .070 & .831 & .011 & .125 & .917 \\
\hline N. observ. & 261,470 & 133,944 & 11,402 & 939,273 & 735,434 & 170,040 \\
\hline \multirow[t]{3}{*}{ N. individuals } & 14,278 & 17,513 & 8,008 & 57,281 & 82,880 & 71,596 \\
\hline & \multicolumn{6}{|c|}{ Panel C: By firm size } \\
\hline & $\begin{array}{l}\text { Firms wi } \\
\text { (1) } \\
\text { PERMANENT } \\
\text { at t-1 }\end{array}$ & $\begin{array}{c}10 \text { or fewer er } \\
\text { (2) } \\
\text { FIXED-TERM } \\
\text { at } \mathrm{t}-1\end{array}$ & $\begin{array}{c}\text { loyees } ¥ \\
\text { (3) } \\
\text { NON-WORK } \\
\text { at t-1 }\end{array}$ & $\begin{array}{l}\text { Firms witt } \\
\text { (1) } \\
\text { PERMANENT } \\
\text { at t-1 }\end{array}$ & $\begin{array}{c}\text { 1ore than } 100 \\
\text { (2) } \\
\text { FIXED-TERM } \\
\text { at } t-1\end{array}$ & $\begin{array}{c}\text { iployees } ¥ \\
\text { (3) } \\
\text { NON-WORK } \\
\text { at t-1 }\end{array}$ \\
\hline $\begin{array}{l}\text { PERMANENT } \\
\text { at } \mathrm{t}\end{array}$ & $\begin{array}{l}-.002^{*} \\
(.001)\end{array}$ & $\begin{array}{c}-.032 * * * \\
(.011)\end{array}$ & $\begin{array}{l}-.145^{*} \\
(.090)\end{array}$ & $\begin{array}{l}.000 \\
(.001)\end{array}$ & $\begin{array}{l}-.024^{*} \\
(.014)\end{array}$ & $\begin{array}{l}-.093 \\
(.097)\end{array}$ \\
\hline $\begin{array}{l}\text { Pre-99 mean } \\
\text { probability }\end{array}$ & .998 & .049 & .194 & .998 & .051 & .224 \\
\hline $\begin{array}{l}\text { NON-WORK } \\
\text { at } \mathrm{t}\end{array}$ & $\begin{array}{l}.004^{* *} \\
(.002)\end{array}$ & $\begin{array}{l}.024^{* *} \\
(.011)\end{array}$ & $\begin{array}{l}.017 \\
(.014)\end{array}$ & $\begin{array}{l}.000 \\
(.001)\end{array}$ & $\begin{array}{c}.007 \\
(.014)\end{array}$ & $\begin{array}{l}.008 \\
(.016)\end{array}$ \\
\hline $\begin{array}{l}\text { Pre-99 mean } \\
\text { probability }\end{array}$ & .007 & .080 & .946 & .006 & .102 & .934 \\
\hline $\begin{array}{l}\text { N. observ. } \\
\text { N. individuals }\end{array}$ & $\begin{array}{c}308,654 \\
23,594\end{array}$ & $\begin{array}{c}189,893 \\
40,135\end{array}$ & $\begin{array}{c}119,949 \\
23,589\end{array}$ & $\begin{array}{c}323,994 \\
21,229\end{array}$ & $\begin{array}{c}233,738 \\
40,343\end{array}$ & $\begin{array}{c}124,128 \\
24,164\end{array}$ \\
\hline
\end{tabular}

Note: $¥$ In our sample, $50 \%$ of firms have 10 or fewer employees. For other details, see Notes in Table 3 . 
Table 7. Heterogeneity Analysis

The Effect of the 1999 Law on Childbearing-Aged Women's Wages

(Control group is childbearing aged men)

Individual FE Model

\begin{tabular}{|c|c|c|c|c|c|c|}
\hline & \multicolumn{6}{|c|}{ Panel A: By eligibility status } \\
\hline & \multicolumn{3}{|c|}{ Eligible Women } & \multicolumn{3}{|c|}{ Non-Eligible Women } \\
\hline & $\begin{array}{c}\text { (1) } \\
\text { PERMANENT } \\
\text { at t-1 }\end{array}$ & $\begin{array}{c}\text { (2) } \\
\text { FIXED-TERM } \\
\text { at t-1 }\end{array}$ & $\begin{array}{c}\text { (3) } \\
\text { NON-WORK } \\
\text { at t-1 }\end{array}$ & $\begin{array}{c}\text { (1) } \\
\text { PERMANENT } \\
\text { at t-1 }\end{array}$ & $\begin{array}{c}\text { (2) } \\
\text { FIXED-TERM } \\
\text { at } \mathrm{t}-1\end{array}$ & $\begin{array}{c}\text { (3) } \\
\text { NON-WORK } \\
\text { at t-1 }\end{array}$ \\
\hline $\begin{array}{l}\text { Change in the } \\
\text { gender wage } \\
\text { gap }\end{array}$ & $\begin{array}{c}-.028^{* * *} \\
(.006)\end{array}$ & $\begin{array}{c}-.064 * * * \\
(.015)\end{array}$ & $\begin{array}{c}-.122 * * * \\
(.039)\end{array}$ & $\begin{array}{c}-.024^{* * *} \\
(.007)\end{array}$ & $\begin{array}{c}-.064^{* * *} \\
(.013)\end{array}$ & $\begin{array}{c}-.103 * * * \\
(.030)\end{array}$ \\
\hline $\begin{array}{l}\text { Pre-99 mean } \\
\text { probability }\end{array}$ & 2.185 & 2.025 & 2.046 & 2.136 & 1.997 & 2.031 \\
\hline N. observ. & 384,353 & 159,461 & 28,451 & 798,489 & 645,644 & 141,518 \\
\hline \multirow[t]{4}{*}{ N. individuals } & 14,840 & 15,259 & 12,333 & 52,372 & 74,295 & 61,083 \\
\hline & \multicolumn{6}{|c|}{ Panel B: By occupation } \\
\hline & \multicolumn{3}{|c|}{ White-Collar } & \multicolumn{3}{|c|}{ Blue-Collar } \\
\hline & $\begin{array}{c}\text { (1) } \\
\text { PERMANENT } \\
\text { at t-1 }\end{array}$ & $\begin{array}{c}\text { (2) } \\
\text { FIXED-TERM } \\
\text { at } \mathrm{t}-1\end{array}$ & $\begin{array}{c}\text { (3) } \\
\text { NON-WORK } \\
\text { at t-1 }\end{array}$ & $\begin{array}{c}\text { (1) } \\
\text { PERMANENT } \\
\text { at } \mathrm{t}-1\end{array}$ & $\begin{array}{c}\text { (2) } \\
\text { FIXED-TERM } \\
\text { at } \mathrm{t}-1\end{array}$ & $\begin{array}{c}\text { (3) } \\
\text { NON-WORK } \\
\text { at t-1 }\end{array}$ \\
\hline $\begin{array}{l}\text { Change in the } \\
\text { gender wage } \\
\text { gap }\end{array}$ & $\begin{array}{c}-.032 * * * \\
(.013)\end{array}$ & $\begin{array}{c}-.068 * * * \\
(.025)\end{array}$ & $\begin{array}{l}-.133 \\
(.116)\end{array}$ & $\begin{array}{c}-.025 * * * \\
(.005)\end{array}$ & $\begin{array}{c}-.041 * * * \\
(.013)\end{array}$ & $\begin{array}{c}-.078 * * * \\
(.029)\end{array}$ \\
\hline $\begin{array}{l}\text { Pre-99 mean } \\
\text { probability }\end{array}$ & 2.531 & 2.384 & 2.287 & 2.060 & 1.875 & 1.921 \\
\hline N. observ. & 261,470 & 133,944 & 11,402 & 939,273 & 735,434 & 170,040 \\
\hline \multirow[t]{3}{*}{ N. individuals } & 14,278 & 17,513 & 8,008 & 57,281 & 82,880 & 71,596 \\
\hline & \multicolumn{6}{|c|}{ Panel C: By firm size } \\
\hline & $\begin{array}{l}\text { Firms wi } \\
(1) \\
\text { PERMANENT } \\
\text { at t-1 }\end{array}$ & $\begin{array}{c}10 \text { or fewer er } \\
\text { (2) } \\
\text { FIXED-TERM } \\
\text { at } t-1\end{array}$ & $\begin{array}{c}\text { ployees } ¥ \\
\text { (3) } \\
\text { NON-WORK } \\
\text { at t-1 }\end{array}$ & $\begin{array}{l}\text { Firms with } \\
\text { (1) } \\
\text { PERMANENT } \\
\text { at } \mathrm{t}-1\end{array}$ & $\begin{array}{c}\text { nore than } 100 \\
\text { (2) } \\
\text { FIXED-TERM } \\
\text { at t-1 }\end{array}$ & $\begin{array}{c}\text { nployees } ¥ \\
\text { (3) } \\
\text { NON-WORK } \\
\text { at t-1 }\end{array}$ \\
\hline $\begin{array}{l}\text { Change in the } \\
\text { gender wage } \\
\text { gap }\end{array}$ & $\begin{array}{c}-.022 * * * \\
(.011)\end{array}$ & $\begin{array}{c}-.053^{* *} \\
(.025)\end{array}$ & $\begin{array}{l}.031 \\
(.108)\end{array}$ & $\begin{array}{c}-.031^{* * *} \\
(.010)\end{array}$ & $\begin{array}{c}-.071 * * * \\
(.030)\end{array}$ & $\begin{array}{l}-.027 \\
(.153)\end{array}$ \\
\hline $\begin{array}{l}\text { Pre-99 mean } \\
\text { probability }\end{array}$ & 1.950 & 1.870 & 1.881 & 2.353 & 2.189 & 2.135 \\
\hline N. observ. & 302,368 & 162,331 & 16,906 & 319,349 & 201,662 & 21,836 \\
\hline N. individuals & 22,931 & 34,152 & 11,993 & 20,583 & 34,873 & 14,239 \\
\hline
\end{tabular}

Note: see Notes in Table 3. 


\section{APPENDIX}


Table A.1. Robustness Checks: The Effect of the 1999 Law on Employment Transitions

\begin{tabular}{|c|c|c|c|}
\hline & \multicolumn{3}{|c|}{$\begin{array}{c}\text { Panel A } \\
\text { Control group is childbearing aged men who are not and have not been eligible }\end{array}$} \\
\hline & $\begin{array}{c}\text { (1) } \\
\text { PERMANENT at } \mathrm{t}-1\end{array}$ & $\begin{array}{l}\text { (2) } \\
\text { FIXED-TERM at } t-1\end{array}$ & $\begin{array}{c}\text { (3) } \\
\text { NON-WORK at t-1 }\end{array}$ \\
\hline PERMANENT at $\mathrm{t}$ & $\begin{array}{l}.000 \\
(.001)\end{array}$ & $\begin{array}{c}-.012^{* * *} \\
(.004)\end{array}$ & $\begin{array}{l}-.004 \\
(.022)\end{array}$ \\
\hline NON-WORK at t & $\begin{array}{c}.004^{* * *} \\
(.001)\end{array}$ & $\begin{array}{c}.043 * * * \\
(.006)\end{array}$ & $\begin{array}{c}.040 * * * \\
(.006)\end{array}$ \\
\hline N. obs. & $1,085,345$ & 983,564 & 708,819 \\
\hline \multirow[t]{3}{*}{ N. individuals } & 64,311 & 91,290 & 73,787 \\
\hline & Using only individue & $\begin{array}{l}\text { Panel } \mathrm{B}^{\varphi} \\
\text { t t-1 were working i } \\
\text { are not under-repre }\end{array}$ & ccupations in which \\
\hline & $\begin{array}{c}\text { (1) } \\
\text { PERMANENT at } \mathrm{t}-1\end{array}$ & $\begin{array}{c}\text { (2) } \\
\text { FIXED-TERM at t-1 }\end{array}$ & $\begin{array}{c}\text { (3) } \\
\text { NON-WORK at t-1 }\end{array}$ \\
\hline PERMANENT at $\mathrm{t}$ & $\begin{array}{l}-.001 \\
(.001)\end{array}$ & $\begin{array}{c}-.019 * * * \\
(.005)\end{array}$ & $\begin{array}{l}.008 \\
(.022)\end{array}$ \\
\hline NON-WORK at t & $\begin{array}{l}.003 * * \\
(.001)\end{array}$ & $\begin{array}{c}.024^{* * *} \\
(.006)\end{array}$ & $\begin{array}{l}.014^{* *} \\
(.006)\end{array}$ \\
\hline N. obs. & 750,912 & 677,162 & 136,396 \\
\hline \multirow[t]{3}{*}{ N. individuals } & 49,106 & 83,269 & 64,042 \\
\hline & & $\begin{array}{c}\text { Panel C } \\
\text { viduals without chilc }\end{array}$ & \\
\hline & $\begin{array}{c}\text { (1) } \\
\text { PERMANENT at } t-1\end{array}$ & $\begin{array}{c}\text { (2) } \\
\text { FIXED-TERM at t-1 }\end{array}$ & $\begin{array}{c}\text { (3) } \\
\text { NON-WORK at t-1 }\end{array}$ \\
\hline PERMANENT at $\mathrm{t}$ & $\begin{array}{l}-.001 \\
(.001)\end{array}$ & $\begin{array}{c}-.016^{* * *} \\
(.004)\end{array}$ & $\begin{array}{l}-.021 \\
(.021)\end{array}$ \\
\hline NON-WORK at t & $\begin{array}{l}.006^{* * *} \\
(.001)\end{array}$ & $\begin{array}{l}.043 * * * \\
(.006)\end{array}$ & $\begin{array}{c}.036 * * * \\
(.006)\end{array}$ \\
\hline N. obs & 951,798 & 903,007 & 629,876 \\
\hline \multirow[t]{3}{*}{$\mathrm{N}$. individuals } & 62,199 & 88,356 & 70,127 \\
\hline & & $\begin{array}{c}\text { Panel D } \\
\text { out construction wo }\end{array}$ & \\
\hline & $\begin{array}{c}\text { (1) } \\
\text { PERMANENT at } \mathrm{t}-1\end{array}$ & $\begin{array}{c}\text { (2) } \\
\text { FIXED-TERM at t-1 }\end{array}$ & $\begin{array}{c}\text { (3) } \\
\text { NON-WORK at t-1 }\end{array}$ \\
\hline PERMANENT at $\mathrm{t}$ & $\begin{array}{l}-.000 \\
(.001)\end{array}$ & $\begin{array}{c}-.010 * * * \\
(.004)\end{array}$ & $\begin{array}{l}-.026 \\
(.020)\end{array}$ \\
\hline NON-WORK at t & $\begin{array}{l}.005^{* * *} \\
(.001)\end{array}$ & $\begin{array}{c}.028 * * * \\
(.005)\end{array}$ & $\begin{array}{c}.030 * * * \\
(.006)\end{array}$ \\
\hline N. observ. & $1,156,767$ & 894,697 & 689,748 \\
\hline N. individuals & 65,809 & 93,027 & 74,040 \\
\hline \multicolumn{4}{|c|}{$\begin{array}{l}\text { Note. Numbers in parentheses are robust standard errors allowing for intra cluster (individual) correlation. } \\
\text { *** Significant at the } 1 \% \text { level. }{ }^{* *} \text { Significant at the } 5 \% \text { level. } * \text { Significant at the } 10 \% \text { level. Childbearing agec } \\
\text { women (men) are women (men) aged } 23 \text { to } 44 \text {. All models control for education, education interacted with being a } \\
\text { woman, number of children and number of children interacted with being a woman, age, age squared, region } \\
\text { dummies, the regional unemployment rate, a linear time trend, a linear time trend interacted with being a woman } \\
\text { woman dummy, a post- } 1999 \text { dummy, and the interaction between these two variables. The regressions where the } \\
\text { dependent variable is working under a PERMANENT contract at } t \text { condition on being working at } t \text { and therefore the } \\
\text { coefficient of interest indicates the probability of a transition to a permanent contract as opposed to a fixed-term } \\
\text { contract. }{ }^{\varphi} \text { Individuals in occupations where the share of females in total employment is above } 50 \% \text {. }\end{array}$} \\
\hline
\end{tabular}


Table A.2. Robustness Checks: The Effect of the 1999 Law on Wages

\begin{tabular}{|c|c|c|c|}
\hline & \multicolumn{3}{|c|}{$\begin{array}{c}\text { Panel A } \\
\text { Control group is childbearing aged men who are not and have not been eligible }\end{array}$} \\
\hline & $\begin{array}{c}\text { (1) } \\
\text { PERMANENT at t-1 }\end{array}$ & $\begin{array}{l}\text { (2) } \\
\text { FIXED-TERM at t-1 }\end{array}$ & $\begin{array}{c}\text { (3) } \\
\text { NON-WORK at t-1 }\end{array}$ \\
\hline $\begin{array}{l}\text { Change in the gender } \\
\text { wage gap }\end{array}$ & $\begin{array}{c}-.018^{* * *} \\
(.006)\end{array}$ & $\begin{array}{c}-.049 * * * \\
(.013)\end{array}$ & $\begin{array}{c}-.062 * * * \\
(.031)\end{array}$ \\
\hline N. obs. & $1,085,345$ & 983,564 & 708,819 \\
\hline \multirow[t]{3}{*}{ N. individuals } & 64,311 & 91,290 & 73,787 \\
\hline & \multicolumn{3}{|c|}{ 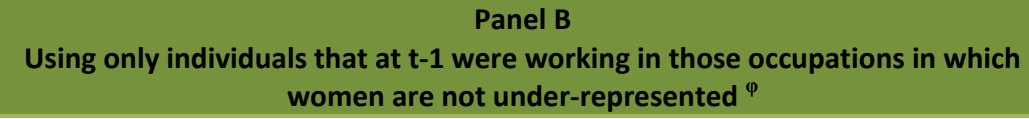 } \\
\hline & $\begin{array}{c}\text { (1) } \\
\text { PERMANENT at t-1 }\end{array}$ & $\begin{array}{l}\text { (2) } \\
\text { FIXED-TERM at t-1 }\end{array}$ & $\begin{array}{c}(3) \\
\text { NON-WORK at t-1 }\end{array}$ \\
\hline $\begin{array}{l}\text { Change in the gender } \\
\text { wage gap }\end{array}$ & $\begin{array}{c}-.028 * * * \\
(.007)\end{array}$ & $\begin{array}{c}-.062 * * * \\
(.013)\end{array}$ & $\begin{array}{c}-.090 * * * \\
(.032)\end{array}$ \\
\hline N. obs. & 750,912 & 677,162 & 136,396 \\
\hline \multirow[t]{3}{*}{ N. individuals } & 49,106 & 83,269 & 64,042 \\
\hline & \multicolumn{3}{|c|}{$\begin{array}{l}\text { Panel C } \\
\text { Individuals without children }\end{array}$} \\
\hline & $\begin{array}{c}(1) \\
\text { PERMANENT at } t-1\end{array}$ & $\begin{array}{l}\text { (2) } \\
\text { FIXED-TERM at } t-1\end{array}$ & $\begin{array}{c}\text { (3) } \\
\text { NON-WORK at t-1 }\end{array}$ \\
\hline $\begin{array}{l}\text { Change in the gender } \\
\text { wage gap }\end{array}$ & $\begin{array}{c}-.024 * * * \\
(.006)\end{array}$ & $\begin{array}{c}-.055^{* * *} \\
(.012)\end{array}$ & $\begin{array}{c}-.074 * * * \\
(.030)\end{array}$ \\
\hline N. obs & 951,798 & 903,007 & 629,876 \\
\hline \multirow[t]{3}{*}{ N. individuals } & 62,199 & 88,356 & 70,127 \\
\hline & \multicolumn{3}{|c|}{$\begin{array}{c}\text { Panel D } \\
\text { Without construction workers }\end{array}$} \\
\hline & $\begin{array}{c}(1) \\
\text { PERMANENT at } t-1 \\
\end{array}$ & $\begin{array}{c}\text { (2) } \\
\text { FIXED-TERM at t-1 }\end{array}$ & $\begin{array}{c}\text { (3) } \\
\text { NON-WORK at t-1 }\end{array}$ \\
\hline $\begin{array}{l}\text { Change in the gender } \\
\text { wage gap }\end{array}$ & $\begin{array}{c}-.029 * * * \\
(.005)\end{array}$ & $\begin{array}{c}-.056^{* * *} \\
(.012)\end{array}$ & $\begin{array}{c}-.094 * * * \\
(.028)\end{array}$ \\
\hline N. obs & $1,156,767$ & 894,697 & 689,748 \\
\hline N. individuals & 65,809 & 93,027 & 74,040 \\
\hline
\end{tabular}

Note. Numbers between parentheses are robust standard errors, allowing for intra cluster (individual) correlation. *** Significant at the $1 \%$ level. ** Significant at the $5 \%$ level. * Significant at the $10 \%$ level. The change in the gender wage gap is given by the coefficient of interest in equation $(x)$ and captures the change in the gender wage gap post law period, relative to the pre law period, and after controlling for the covariates. Childbearing aged women (men) are women (men) aged 23 to 44 . All models control for education, education interacted with being a woman, number of children and number of children interacted with being a woman, age, age squared, region dummies, the regional unemployment rate, a linear time trend, a linear time trend interacted with being a woman, woman dummy, a post-1999 dummy, and the interaction between these two variables. ${ }^{\varphi}$ Individuals in occupations where the share of females in total employment is above $50 \%$. 
Table A.3. Robustness Checks: The Effect of the 1999 Law on Employment Transitions

\begin{tabular}{|c|c|c|c|}
\hline & \multicolumn{3}{|c|}{$\begin{array}{l}\text { Panel A. DDD Model with individual FE - Control includes Men and Women Older } \\
\text { than } 45 \text { in Addition to Young Men }{ }^{r}\end{array}$} \\
\hline & $\begin{array}{c}\text { (1) } \\
\text { PERMANENT at } \mathrm{t}-1\end{array}$ & $\begin{array}{l}\text { (2) } \\
\text { FIXED-TERM at } t-1\end{array}$ & $\begin{array}{c}\text { (3) } \\
\text { NON-WORK at t-1 }\end{array}$ \\
\hline PERMANENT at $\mathrm{t}$ & $\begin{array}{c}-.008 * * * \\
(.000)\end{array}$ & $\begin{array}{c}-.008^{* * *} \\
(.003)\end{array}$ & $\begin{array}{c}-.040 * * \\
(.019)\end{array}$ \\
\hline NON-WORK at t & $\begin{array}{c}.009 * * * \\
(.001)\end{array}$ & $\begin{array}{c}.046 * * * \\
(.004)\end{array}$ & $\begin{array}{c}.026 * * * \\
(.005)\end{array}$ \\
\hline N. obs. & $2,497,224$ & $1,208,672$ & 846,047 \\
\hline N. individuals & 116,292 & 113,080 & 89,551 \\
\hline & \multicolumn{3}{|c|}{$\begin{array}{l}\text { Panel B. DD Model with individual FE - Region Interacted with post1999 Dummy and } \\
\text { Region Interacted with Treatment }\end{array}$} \\
\hline & $\begin{array}{c}\text { (1) } \\
\text { PERMANENT at } \mathrm{t}-\mathbf{1}\end{array}$ & $\begin{array}{c}\text { (2) } \\
\text { FIXED-TERM at t-1 }\end{array}$ & $\begin{array}{c}\text { (3) } \\
\text { NON-WORK at t-1 }\end{array}$ \\
\hline PERMANENT at $\mathrm{t}$ & $\begin{array}{l}-.000 \\
(.001)\end{array}$ & $\begin{array}{c}-.017^{* * *} \\
(.004)\end{array}$ & $\begin{array}{l}-.025 \\
(.020)\end{array}$ \\
\hline NON-WORK at t & $\begin{array}{c}.005^{* * *} \\
(.001)\end{array}$ & $\begin{array}{c}.046^{* * *} \\
(.005)\end{array}$ & $\begin{array}{c}.041^{* * *} \\
(.006)\end{array}$ \\
\hline N. obs. & $1,226,822$ & $1,014,089$ & 738,253 \\
\hline N. individuals & 69,233 & 95,794 & 77,026 \\
\hline & \multicolumn{3}{|c|}{$\begin{array}{c}\text { Panel C. DD Model with individual FE - Year fixed-effects and time trend interacted } \\
\text { with treatment }\end{array}$} \\
\hline & $\begin{array}{c}\text { (1) } \\
\text { PERMANENT at } \mathrm{t}-1\end{array}$ & $\begin{array}{c}\text { (2) } \\
\text { FIXED-TERM at t-1 }\end{array}$ & $\begin{array}{c}\text { (3) } \\
\text { NON-WORK at t-1 }\end{array}$ \\
\hline PERMANENT at $\mathrm{t}$ & $\begin{array}{l}-.000 \\
(.001)\end{array}$ & $\begin{array}{c}-.018^{* * *} \\
(.004)\end{array}$ & $\begin{array}{l}-.026 \\
(.019)\end{array}$ \\
\hline NON-WORK at t & $\begin{array}{l}.005^{* * *} \\
(.001)\end{array}$ & $\begin{array}{c}.044^{* * *} \\
(.005)\end{array}$ & $\begin{array}{c}.039 * * * \\
(.004)\end{array}$ \\
\hline N. obs & $1,226,822$ & $1,014,089$ & 738,253 \\
\hline N. individuals & 69,233 & 95,794 & 77,026 \\
\hline & \multicolumn{3}{|c|}{ Panel D. DD Model with individual FE - Quadratic and Linear Trend } \\
\hline & $\begin{array}{c}\text { (1) } \\
\text { PERMANENT at t-1 }\end{array}$ & $\begin{array}{c}\text { (2) } \\
\text { FIXED-TERM at t-1 }\end{array}$ & $\begin{array}{c}(3) \\
\text { NON-WORK at t-1 }\end{array}$ \\
\hline PERMANENT at $\mathrm{t}$ & $\begin{array}{l}-.000 \\
(.000)\end{array}$ & $\begin{array}{c}-.017^{* * *} \\
(.004)\end{array}$ & $\begin{array}{l}-.025 \\
(.020)\end{array}$ \\
\hline NON-WORK at t & $\begin{array}{c}.005^{* * *} \\
(.001)\end{array}$ & $\begin{array}{l}.045^{* * *} \\
(.005)\end{array}$ & $\begin{array}{c}.041^{* * *} \\
(.005)\end{array}$ \\
\hline N. obs. & $1,226,822$ & $1,014,089$ & 738,253 \\
\hline N. individuals & 69,233 & 95,794 & 77,026 \\
\hline & \multicolumn{3}{|c|}{ Panel E. Placebo Test - DD Model with individual FE - 1996-97 versus 1998-99 } \\
\hline & $\begin{array}{c}\text { (1) } \\
\text { PERMANENT at t-1 }\end{array}$ & $\begin{array}{c}\text { (2) } \\
\text { FIXED-TERM at t-1 }\end{array}$ & $\begin{array}{c}\text { (3) } \\
\text { NON-WORK at t-1 }\end{array}$ \\
\hline PERMANENT at $\mathrm{t}$ & $\begin{array}{c}.000 \\
(.001)\end{array}$ & $\begin{array}{l}.016^{*} \\
(.010)\end{array}$ & $\begin{array}{c}.042 \\
(.073)\end{array}$ \\
\hline NON-WORK at t & $\begin{array}{l}.000 \\
(.002)\end{array}$ & $\begin{array}{l}-.013 \\
(.009)\end{array}$ & $\begin{array}{l}.017 \\
(.012)\end{array}$ \\
\hline N. observ. & 99,050 & 49,404 & 40,091 \\
\hline N. individuals & 9,397 & 10,210 & 6,431 \\
\hline
\end{tabular}

Note. Numbers between parentheses are robust standard errors, allowing for intra cluster (individual) correlation. $* * *$ Significant at the $1 \%$ level. ${ }^{* *}$ Significant at the $5 \%$ level. ${ }^{*}$ Significant at the $10 \%$ level. Childbearing aged women (men) are women (men) aged 23 to 44 . All models control for education, education interacted with gender, number of children and number of children interacted with gender, age, age2, region dummies, the regional unemployment rate, a linear time trend, a linear time trend interacted with gender, gender and a post1999 dummy. The regressions where the dependent variable is working under a PERMANENT contract at $t$ condition on being working at $\mathrm{t}$ and therefore the coefficient of interest indicates the probability of a transition into a permanent contract as opposed to a fixed-term contract. 
Table A.4. Robustness Checks: The Effect of the 1999 Law on Wages

\begin{tabular}{|c|c|c|c|}
\hline & \multicolumn{3}{|c|}{$\begin{array}{l}\text { Panel A } \\
\text { DDD Model with individual FE - Control includes Men and Women Older than } 45 \text { in } \\
\text { Addition to Young Men }\end{array}$} \\
\hline & $\begin{array}{c}\text { (1) } \\
\text { PERMANENT at } \mathrm{t}-1\end{array}$ & $\begin{array}{c}\text { (2) } \\
\text { FIXED-TERM at t-1 }\end{array}$ & $\begin{array}{c}\text { (3) } \\
\text { NON-WORK at t-1 }\end{array}$ \\
\hline $\begin{array}{l}\text { Change in the gender } \\
\text { wage gap }\end{array}$ & $\begin{array}{c}-.050 * * * \\
(.004)\end{array}$ & $\begin{array}{c}-.075^{* * *} \\
(.010)\end{array}$ & $\begin{array}{c}-.068 * * * \\
(.025)\end{array}$ \\
\hline N. obs. & $2,497,224$ & $1,208,672$ & 846,047 \\
\hline \multirow[t]{3}{*}{ N. individuals } & 116,292 & 113,080 & 89,551 \\
\hline & \multicolumn{3}{|c|}{$\begin{array}{c}\text { Panel B } \\
\text { DD Model with individual FE - Region Interacted with post1999 Dummy and Region } \\
\text { Interacted with Treatment }\end{array}$} \\
\hline & $\begin{array}{c}\text { (1) } \\
\text { PERMANENT at t-1 }\end{array}$ & $\begin{array}{c}\text { (2) } \\
\text { FIXED-TERM at t-1 }\end{array}$ & $\begin{array}{c}\text { (3) } \\
\text { NON-WORK at t-1 }\end{array}$ \\
\hline $\begin{array}{l}\text { Change in the gender } \\
\text { wage gap }\end{array}$ & $\begin{array}{c}-.028 * * * \\
(.005)\end{array}$ & $\begin{array}{c}-.054 * * * \\
(.012)\end{array}$ & $\begin{array}{c}-.090 * * * \\
(.028)\end{array}$ \\
\hline N. obs. & $1,226,822$ & $1,014,089$ & 738,253 \\
\hline \multirow[t]{3}{*}{ N. individuals } & 69,233 & 95,794 & 77,026 \\
\hline & \multicolumn{3}{|c|}{$\begin{array}{c}\text { Panel C } \\
\text { DD Model with individual FE - Year fixed-effects and time trend interacted with } \\
\text { treatment }\end{array}$} \\
\hline & $\begin{array}{c}\text { (1) } \\
\text { PERMANENT at t-1 }\end{array}$ & $\begin{array}{c}\text { (2) } \\
\text { FIXED-TERM at t-1 }\end{array}$ & $\begin{array}{c}\text { (3) } \\
\text { NON-WORK at t-1 }\end{array}$ \\
\hline $\begin{array}{l}\text { Change in the gender } \\
\text { wage gap }\end{array}$ & $\begin{array}{c}-.026 * * * \\
(.005)\end{array}$ & $\begin{array}{c}-.053 * * * \\
(.011)\end{array}$ & $\begin{array}{c}-.084 * * * \\
(.027)\end{array}$ \\
\hline N. obs & $1,226,822$ & $1,014,089$ & 738,253 \\
\hline \multirow{3}{*}{ N. individuals } & 69,233 & 95,794 & 77,026 \\
\hline & \multicolumn{3}{|c|}{$\begin{array}{c}\text { Panel D } \\
\text { DD Model with individual FE - Quadr }\end{array}$} \\
\hline & $\begin{array}{c}\text { (1) } \\
\text { PERMANENT at t-1 }\end{array}$ & $\begin{array}{c}\text { (2) } \\
\text { FIXED-TERM at t-1 }\end{array}$ & $\begin{array}{c}\text { (3) } \\
\text { NON-WORK at t-1 }\end{array}$ \\
\hline $\begin{array}{l}\text { Change in the gender } \\
\text { wage gap }\end{array}$ & $\begin{array}{c}-.018 * * * \\
(.006)\end{array}$ & $\begin{array}{l}.013 \\
(.012)\end{array}$ & $\begin{array}{l}.005 \\
(.032)\end{array}$ \\
\hline N. obs. & $1,226,822$ & $1,014,089$ & 738,253 \\
\hline \multirow[t]{3}{*}{ N. individuals } & 69,233 & 95,794 & 77,026 \\
\hline & \multicolumn{3}{|c|}{ Placebo Test - DD Model with individual FE - 1996-97 versus 1998-99 } \\
\hline & $\begin{array}{c}\text { (1) } \\
\text { PERMANENT at } \mathrm{t}-1\end{array}$ & $\begin{array}{c}\text { (2) } \\
\text { FIXED-TERM at t-1 }\end{array}$ & $\begin{array}{c}\text { (3) } \\
\text { NON-WORK at t-1 }\end{array}$ \\
\hline $\begin{array}{l}\text { Change in the gender } \\
\text { wage gap }\end{array}$ & $\begin{array}{l}.000 \\
(.005)\end{array}$ & $\begin{array}{l}.020^{*} \\
(.012)\end{array}$ & $\begin{array}{l}-.092 \\
(.090)\end{array}$ \\
\hline N. observ. & 99,050 & 49,404 & 40,091 \\
\hline N. individuals & 9,397 & 10,210 & 6,431 \\
\hline
\end{tabular}

Note. Numbers in parentheses are robust standard errors, allowing for intra cluster (individual) correlation.

*** Significant at the $1 \%$ level. ** Significant at the $5 \%$ level. * Significant at the $10 \%$ level. The change in the gender wage gap is given by the coefficient of interest in equation $(x)$ and captures the change in the gender wage gap post law period, relative to the pre law period, and after controlling for the covariates. Childbearing aged women (men) are women (men) aged 23 to 44 . All models control for education, education interacted with being a woman, number of children and number of children interacted with being a woman, age, age squared, region dummies, the regional unemployment rate, a linear time trend, a linear time trend interacted with being a woman, woman dummy, a post-1999 dummy, and the interaction between these two variables. The regressions where the dependent variable is PERMANENT at $t$ condition on being working at $t$. 
Table A.5. Was the Law Effective?

Heterogeneity Analysis

(Treatment: Women with Children 0-6

(Control group is women with children 7-12) ${ }^{\Upsilon}$

\begin{tabular}{|c|c|c|c|c|}
\hline & \multicolumn{4}{|c|}{ Panel A. By Occupation } \\
\hline & \multicolumn{2}{|c|}{ Blue-Collar } & \multicolumn{2}{|c|}{ White-Collar } \\
\hline & $\begin{array}{c}\text { (1) } \\
\text { PERMANENT } \\
\text { at t-1 }\end{array}$ & $\begin{array}{c}\text { (2) } \\
\text { FIXED-TERM } \\
\text { at t-1 }\end{array}$ & $\begin{array}{c}\text { (3) } \\
\text { PERMANENT } \\
\text { at t-1 }\end{array}$ & $\begin{array}{c}\text { (4) } \\
\text { FIXED-TERM } \\
\text { at t-1 }\end{array}$ \\
\hline $\begin{array}{l}\text { PART-TIME at } t \\
\text { (being Full-time at } t-1 \\
\text { and conditional on being on } \\
\text { the same firm) }\end{array}$ & $\begin{array}{c}.006 * * * \\
(.002)\end{array}$ & $\begin{array}{l}-.012 \\
(.023)\end{array}$ & $\begin{array}{c}.002 \\
(.002)\end{array}$ & $\begin{array}{l}-.050 \\
(.041)\end{array}$ \\
\hline Pre-99 mean & .003 & .053 & .001 & .014 \\
\hline N. of observations & 70,290 & 28,855 & 22,554 & 4,800 \\
\hline \multirow[t]{4}{*}{ N. of individuals } & 5,822 & 5,363 & 1,560 & 750 \\
\hline & \multicolumn{4}{|c|}{ Panel B. By Firm Size } \\
\hline & \multicolumn{2}{|c|}{ Firms with 10 or fewer employees } & \multicolumn{2}{|c|}{$\begin{array}{c}\text { Firms with } 100 \text { or more } \\
\text { employees }\end{array}$} \\
\hline & $\begin{array}{c}\text { (1) } \\
\text { PERMANENT } \\
\text { at t-1 }\end{array}$ & $\begin{array}{c}\text { (2) } \\
\text { FIXED-TERM } \\
\text { at t-1 }\end{array}$ & $\begin{array}{c}\text { (3) } \\
\text { PERMANENT } \\
\text { at t-1 }\end{array}$ & $\begin{array}{c}\text { (4) } \\
\text { FIXED-TERM } \\
\text { at t-1 }\end{array}$ \\
\hline $\begin{array}{l}\text { PART-TIME at t } \\
\text { (being Full-time at t-1 } \\
\text { and conditional on being on } \\
\text { the same firm) }\end{array}$ & $\begin{array}{l}.008^{* *} \\
(.004)\end{array}$ & $\begin{array}{c}.010 \\
(.022)\end{array}$ & $\begin{array}{l}.008 * * \\
(.004)\end{array}$ & $\begin{array}{l}-.011 \\
(.025)\end{array}$ \\
\hline Pre-99 mean probability & .002 & .043 & .005 & .068 \\
\hline N. of observations & 35,406 & 8,958 & 29,383 & 8,574 \\
\hline N. of individuals & 3,291 & 2,435 & 2,256 & 1,902 \\
\hline
\end{tabular}

$\checkmark$ Note: Numbers in parentheses are robust standard errors, allowing for intra cluster (individual) correlation.

*** Significant at the $1 \%$ level. ${ }^{* *}$ Significant at the $5 \%$ level. * Significant at the $10 \%$ level. All models control for education, education interacted with being a woman, number of children and number of children interacted with being a woman, age, age squared, region dummies, the regional unemployment rate, a linear time trend, a linear time trend interacted with being a woman, woman dummy, a post-1999 dummy, and the interaction between these two variables. The regressions where the dependent variable is working under a PERMANENT contract at $t$, condition on being working at $\mathrm{t}$. 
Table A.6. The Effect of the 1999 Law on Employment Transitions

By Relevance of Construction Boom

(Control group is childbearing aged men)

Individual FE Model

\begin{tabular}{|c|c|c|c|c|c|c|}
\hline & \multicolumn{6}{|c|}{ Panel A: Coastal versus Non-Coastal } \\
\hline & \multicolumn{3}{|c|}{ Coastal $^{*}$} & \multicolumn{3}{|c|}{ Non-Coastal } \\
\hline & $\begin{array}{c}\text { (1) } \\
\text { PERMANENT } \\
\text { at t-1 }\end{array}$ & $\begin{array}{c}\text { (2) } \\
\text { FIXED-TERM } \\
\text { at t-1 }\end{array}$ & $\begin{array}{c}\text { (3) } \\
\text { NON-WORK } \\
\text { at t-1 }\end{array}$ & $\begin{array}{c}\text { (4) } \\
\text { PERMANENT } \\
\text { at t-1 }\end{array}$ & $\begin{array}{c}\text { (5) } \\
\text { FIXED-TERM } \\
\text { at t-1 }\end{array}$ & $\begin{array}{c}\text { (6) } \\
\text { NON-WORK } \\
\text { at t-1 }\end{array}$ \\
\hline $\begin{array}{l}\text { PERMANENT } \\
\text { at } \mathrm{t}\end{array}$ & $\begin{array}{l}.000 \\
(.001)\end{array}$ & $\begin{array}{l}-.010 * \\
(.005)\end{array}$ & $\begin{array}{l}-.018 \\
(.025)\end{array}$ & $\begin{array}{l}-.001 \\
(.001)\end{array}$ & $\begin{array}{c}-.028 * * * \\
(.006)\end{array}$ & $\begin{array}{l}-.036 \\
(.030)\end{array}$ \\
\hline $\begin{array}{l}\text { Pre-99 mean } \\
\text { probability }\end{array}$ & .997 & .046 & .172 & .996 & .046 & .141 \\
\hline $\begin{array}{l}\text { NON-WORK } \\
\text { at } \mathrm{t}\end{array}$ & $\begin{array}{l}.005^{* * *} \\
(.001)\end{array}$ & $\begin{array}{c}.059 * * * \\
(.007)\end{array}$ & $\begin{array}{c}.039 * * * \\
(.007)\end{array}$ & $\begin{array}{c}.007^{* * *} \\
(.001)\end{array}$ & $\begin{array}{c}.029 * * * \\
(.008)\end{array}$ & $\begin{array}{c}.052^{* * *} \\
(.009)\end{array}$ \\
\hline $\begin{array}{l}\text { Pre-99 mean } \\
\text { probability }\end{array}$ & .010 & .114 & .909 & .011 & .121 & .911 \\
\hline N. observ. & 764,201 & 570,780 & 432,536 & 462,621 & 443,309 & 305,717 \\
\hline \multirow[t]{4}{*}{ N. individuals } & 42,156 & 55,057 & 44,912 & 27,077 & 40,737 & 32,114 \\
\hline & \multicolumn{6}{|c|}{ Panel B: By Growth Rate of Male Employment in Construction } \\
\hline & \multicolumn{3}{|c|}{ High Growth ${ }^{\Phi}$} & \multicolumn{3}{|c|}{ Low Growth } \\
\hline & $\begin{array}{c}\text { (1) } \\
\text { PERMANENT } \\
\text { at t-1 }\end{array}$ & $\begin{array}{c}\text { (2) } \\
\text { FIXED-TERM } \\
\text { at } \mathrm{t}-1\end{array}$ & $\begin{array}{c}\text { (3) } \\
\text { NON-WORK } \\
\text { at t-1 }\end{array}$ & $\begin{array}{c}\text { (4) } \\
\text { PERMANENT } \\
\text { at t-1 }\end{array}$ & $\begin{array}{c}\text { (5) } \\
\text { FIXED-TERM } \\
\text { at } \mathrm{t}-1\end{array}$ & $\begin{array}{c}(6) \\
\text { NON-WORK } \\
\text { at t-1 }\end{array}$ \\
\hline $\begin{array}{l}\text { PERMANENT } \\
\text { at } \mathrm{t}\end{array}$ & $\begin{array}{l}.001 \\
(.001)\end{array}$ & $\begin{array}{c}-.016^{* * *} \\
(.006)\end{array}$ & $\begin{array}{l}-.037 \\
(.029)\end{array}$ & $\begin{array}{l}-.000 \\
(.001)\end{array}$ & $\begin{array}{c}-.015 * * * \\
(.005)\end{array}$ & $\begin{array}{l}-.015 \\
(.027)\end{array}$ \\
\hline $\begin{array}{l}\text { Pre-99 mean } \\
\text { probability }\end{array}$ & .997 & .038 & .137 & .997 & .050 & .176 \\
\hline $\begin{array}{l}\text { NON-WORK } \\
\text { at } t\end{array}$ & $\begin{array}{c}.007^{* * *} \\
(.002)\end{array}$ & $\begin{array}{c}.076 * * * \\
(.008)\end{array}$ & $\begin{array}{l}.068^{* * *} \\
(.009)\end{array}$ & $\begin{array}{l}.005^{* * *} \\
(.001)\end{array}$ & $\begin{array}{l}.022 * * * \\
(.007)\end{array}$ & $\begin{array}{l}.025^{* * *} \\
(.008)\end{array}$ \\
\hline $\begin{array}{l}\text { Pre-99 mean } \\
\text { probability }\end{array}$ & .014 & .129 & .913 & .009 & .109 & .907 \\
\hline N. observ. & 434,655 & 465,072 & 337,979 & 792,167 & 549,017 & 400,274 \\
\hline N. individuals & 26,904 & 42,746 & 34,362 & 42,329 & 53,048 & 42,664 \\
\hline
\end{tabular}

Note: Numbers between parentheses are robust standard errors, allowing for intra cluster (individual) correlation. *** Significant at the $1 \%$ level. ${ }^{* *}$ Significant at the $5 \%$ level. ${ }^{*}$ Significant at the $10 \%$ level. Childbearing aged women (men) are women (men) aged 23 to 44 . All models control for education, education interacted with being a woman, number of children and number of children interacted with being a woman, age, age squared, region dummies, the regional unemployment rate, a linear time trend, a linear time trend interacted with being a woman, woman dummy, a post-1999 dummy, and the interaction between these two variables. In the regressions where we estimate the probability of a transition into PERMANENT employment we condition on being employed at $t$ and therefore the coefficient indicates the probability of staying or transitioning into permanent employment as opposed to fixed-term employment. ${ }^{¥}$ Coastal Spanish provinces plus Madrid. ${ }^{\Phi}$ Spanish provinces with a growth rate of the share of male employment in construction above the sample average which is $12 \%$ for the period between 1997 and 2007. 
Table A.7. The Effect of the 1999 Law on Wages

By Relevance of Construction Boom

(Control group is childbearing aged men)

Individual FE Model

\begin{tabular}{|c|c|c|c|c|c|c|}
\hline & \multicolumn{6}{|c|}{ Panel A: Coastal versus Non-Coastal } \\
\hline & \multicolumn{3}{|c|}{ Coastal $^{*}$} & \multicolumn{3}{|c|}{ Non-Coastal } \\
\hline & $\begin{array}{c}\text { (1) } \\
\text { PERMANENT } \\
\text { at t-1 }\end{array}$ & $\begin{array}{c}\text { (2) } \\
\text { FIXED-TERM } \\
\text { at t-1 }\end{array}$ & $\begin{array}{c}\text { (3) } \\
\text { NON-WORK } \\
\text { at t-1 }\end{array}$ & $\begin{array}{c}\text { (4) } \\
\text { PERMANENT } \\
\text { at t-1 }\end{array}$ & $\begin{array}{c}\text { (5) } \\
\text { FIXED-TERM } \\
\text { at t-1 }\end{array}$ & $\begin{array}{c}\text { (6) } \\
\text { NON-WORK } \\
\text { at t }\end{array}$ \\
\hline $\begin{array}{l}\text { Change in the } \\
\text { gender wage } \\
\text { gap }\end{array}$ & $\begin{array}{c}-.029 * * * \\
(.006)\end{array}$ & $\begin{array}{c}-.050 * * * \\
(.014)\end{array}$ & $\begin{array}{c}-.100 * * * \\
(.034)\end{array}$ & $\begin{array}{c}-.026 * * * \\
(.009)\end{array}$ & $\begin{array}{c}-.061^{* * *} \\
(.019)\end{array}$ & $\begin{array}{c}-.059 * * * \\
(.048)\end{array}$ \\
\hline $\begin{array}{l}\text { Pre-99 mean } \\
\text { probability }\end{array}$ & 2.171 & 1.961 & 1.983 & 2.066 & 1.949 & 1.935 \\
\hline N. observ. & 764,201 & 570,780 & 432,536 & 462,621 & 443,309 & 305,717 \\
\hline \multirow[t]{4}{*}{ N. individuals } & 42,156 & 55,057 & 44,912 & 27,077 & 40,737 & 32,114 \\
\hline & \multicolumn{6}{|c|}{ Panel B: By Growth Rate of Male Employment in Construction } \\
\hline & \multicolumn{3}{|c|}{ High Growth $^{\Phi}$} & \multicolumn{3}{|c|}{ Low Growth } \\
\hline & $\begin{array}{c}\text { (1) } \\
\text { PERMANENT } \\
\text { at t-1 }\end{array}$ & $\begin{array}{c}\text { (2) } \\
\text { FIXED-TERM } \\
\text { at } \mathrm{t}-1\end{array}$ & $\begin{array}{c}(3) \\
\text { NON-WORK } \\
\text { at t-1 }\end{array}$ & $\begin{array}{c}\text { (4) } \\
\text { PERMANENT } \\
\text { at t-1 }\end{array}$ & $\begin{array}{c}\text { (5) } \\
\text { FIXED-TERM } \\
\text { at t-1 }\end{array}$ & $\begin{array}{c}\text { (6) } \\
\text { NON-WORK } \\
\text { at t }\end{array}$ \\
\hline $\begin{array}{l}\text { Change in the } \\
\text { gender wage } \\
\text { gap }\end{array}$ & $\begin{array}{c}-.041 * * * \\
(.010)\end{array}$ & $\begin{array}{c}-.056 * * * \\
(.017)\end{array}$ & $\begin{array}{c}-.114 * * * \\
(.040)\end{array}$ & $\begin{array}{c}-.023 * * * \\
(.006)\end{array}$ & $\begin{array}{c}-.054^{* * *} \\
(.015)\end{array}$ & $\begin{array}{l}-.062^{*} \\
(.037)\end{array}$ \\
\hline $\begin{array}{l}\text { Pre-99 mean } \\
\text { probability }\end{array}$ & 2.041 & 1.873 & 1.938 & 2.172 & 2.007 & 1.982 \\
\hline N. observ. & 434,655 & 465,072 & 337,979 & 792,167 & 549,017 & 400,274 \\
\hline N. individuals & 26,904 & 42,746 & 34,362 & 42,329 & 53,048 & 42,664 \\
\hline
\end{tabular}

Note: Numbers between parentheses are robust standard errors, allowing for intra cluster (individual) correlation. *** Significant at the $1 \%$ level. ${ }^{* *}$ Significant at the $5 \%$ level. ${ }^{*}$ Significant at the $10 \%$ level. Childbearing aged women (men) are women (men) aged 23 to 44 . All models control for education, education interacted with being a woman, number of children and number of children interacted with being a woman, age, age squared, region dummies, the regional unemployment rate, a linear time trend, a linear time trend interacted with being a woman, woman dummy, a post-1999 dummy, and the interaction between these two variables. ${ }^{*}$ Coastal Spanish provinces plus Madrid. ${ }^{\Phi}$ Spanish provinces with a growth rate of the share of male employment in construction above the sample average which is $12 \%$ for the period between 1997 and 2007 . 